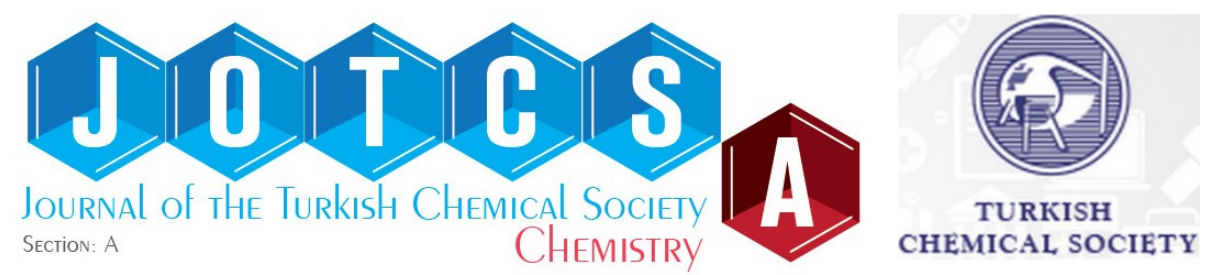

\title{
On the Biological Importance, Preparation, and Uses of Imidazo[1,2- b]pyridazine-Based Compounds
}

\author{
Barbaros AKKURT \\ Istanbul Technical University, Faculty of Science \& Letters, Department of Chemistry, 34469 Maslak, \\ Istanbul, Turkey
}

\begin{abstract}
While studying several pyridazine compounds, the author discovered imidazo[1,2- $b$ ]pyridazine (IMP), which is a very versatile compound class. It has been an inhibitor for many enzymes and also it is used as a brominating reagent in organic syntheses. Owing to its high biological activity, researchers have always considered including this molecule in their final structures. This humble attempt just aims to introduce this very powerful molecule to the readers, primarily of chemical origin, and should not be considered as a full treatise of, especially, the medicinal chemistry of the molecule. This work discusses the inhibitory effects, organic chemistry, applications in material chemistry, and theoretical studies of IMP and related molecules. The readers are hereby encouraged to work with medicinal chemists with the newly prepared molecules including this and similar molecules, in the struggle with many diseases like cancer, Alzheimer's, and others.
\end{abstract}

Keywords: Imidazo[1,2-b]pyridazine, synthesis, inhibitors, applications, reactions.

Submitted: September 25, 2021. Accepted: November 06, 2021.

Cite this: Akkurt B. On the Biological Importance, Preparation, and Uses of Imidazo[1,2-b]pyridazineBased Compounds. JOTCSA. 2021;8(4):1217-50.

DOI: https://doi.org/10.18596/jotcsa.1000771.

*Corresponding author. E-mail: akkurtb@itu.edu.tr.

\section{INTRODUCTION}

This review article discusses the importance of imidazo[1,2-b]pyridazine (IMP) nucleus, which was first synthesized in 1967 by Stanovnik (1). IMP (compound 1, see Figure 1 below) has a structure and numbering scheme depicted in Figure 1. IMP is reported to be an inhibitor including, but not limited to, for the following enzymes: Break point clusterAbelson (BCL-ABL) kinase (2), vascular endothelial growth factor (VEGF) Receptor 2 kinase (3), tumor necrosis factor alpha (4), Bruton's tyrosine kinase (BTK) (5), ATP-competitive mTOR (mammalian target of rapamycin) (6), PDE 10A (7), activin receptor-like kinase 2 (8), Pim kinase (9), deathassociated protein kinase (DAPK) (10), glycogen synthase kinase-3 (11), fibroblast growth factor receptor 1 (FGFR1) (12), dengue fever (13), tyrosine kinase 2 (2), and calcium-dependent protein kinase 1 (14). It has also been reported as an ingredient of anticancer drugs (15), antiparasitic (16), and antiproliferative agents (17), and used as radioligands for tropomyosin receptor kinase family (18). The review article also sheds light on the synthetic works, such as arene $\mathrm{C}-\mathrm{H}$ functionalization (19), addition of osmium carbynes to conjugated systems (20), C-H silylation of IMP (21), photoelectrochemical C-H alkylation (22), photoinduced oxidative activation (23), ceric ammonium nitrate (CAN) oxidation (24), also bromination agents originating from IMP (25). IMP is an n-type unit and was used in the red phosphorescent organic light-emitting devices (26). Photochromic IMP-based iodoargentate hybrid materials were also reported (27). There are a handful of theoretical studies conducted with IMP and its derivatives (28). These all will be discussed adequately in the article.

The imidazo[1,2-b]pyridazine (IMP) (compound 1) has a structure and numbering scheme depicted in Figure 1. 


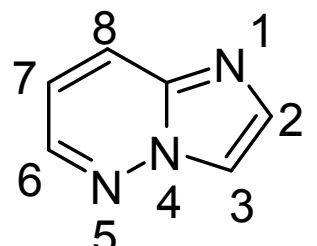

(1)

Figure 1: The IMP nucleus, along with its numbering scheme.

\section{INHIBITORY PROPERTIES OF IMP ON MANY ENZYMES}

\section{Inhibition of Bcr-Abl Kinase of Substituted Imidazopyridazine Scaffold as a Trusted Structure}

Liu and colleagues reported, in a review article, that $B C R$ gene and the $C-A B L$ protooncogene are fused to create the $B C R-A B L$ (break point clusterAbelson) gene, which is considered to be the main cause of chronic myelogenous leukemia (CML) production. To treat $C M L$, selective $B C R-A B L$ kinase inhibitors are employed, but there is a problem, namely, a gatekeeper mutant called as T315I disrupts the interaction between the enzyme and the inhibitor. Some molecules prepared are in the preclinical stage, where many others are employed in the clinical research. Ponatinib is an IMPcontaining drug used in these researches (see Figure 2, compound 2) (2). Another review article states that Ponatinib is approved as an auxilary treatment molecule for chronic myelogenous leukemia (CML) and Philadelphia chromosomepositive acute lymphoblastic leukemia (ALL). The drug, ponatinib, is a multikinase inhibitor and is active against BCR-AbIT315I, BCR-Abl, Flt3, FGFR1, Kit, RET, Src, and VEGFR2 and BCR-Abl is the prime target for treating CML and ALL (29). Pyrazolecontaining IMP-phenylbenzamide derivatives were reported to possess $B C R-A B L$ kinase inhibition. Combinational strategies of scaffold hopping and conformational constraint were employed. The new compounds were screened for BCR-ABL1 kinase inhibitory activity, and most of them showed good inhibitory activity against BCR-ABL1 kinase (30) (See Scheme 2). Ponatinib was reported to be five to seven fold more potent at inhibiting $A B L$ than the mutant, referred to as the ABLT315I, although there are only minimal variations in the binding modes. There are five hydrogen bonds in the binding of ponatinib to $A B L$ and ABLT315I. The conformation is called as "DFG-out". The IMP moiety produces van der Waals interactions with the both lobes of the kinase binding site. The ethynyl link is very important to bind to native and mutant $A B L$ kinase. It forms favorable interactions in the binding. The rigid nature of ethynyl group enables the adoption of correct orientation and correct conformation in the binding site, and important entropic advantage is gained. When binding to the mutant site, the inhibitor conformation is somewhat perturbed and favorable interactions are allowed and steric clash is alleviated. This adjustment is accounted for the loss of potency with the mutant site (31). Ponatinib was also reported to possess an alkyne linker between the IMP and diarylamide (a 2,3-diarylethyne motif) and a slim alkyne moiety was found to be crucial to activity by avoiding steric hindrance (32). Ponatinib (see Figure 2) is used as an antileukemic agent, and is also considered for other anticancer therapies. It is toxic and researchers look for other derivatives of it for improved kinase selectivity as Ponatinib itself is not considered for MNK1 or 2 inhibition, but recent derivatives in which a nitrogen is introduced into the molecule report that the new compounds are potent inhibitors of MNKs (see Figure 3, (33)).

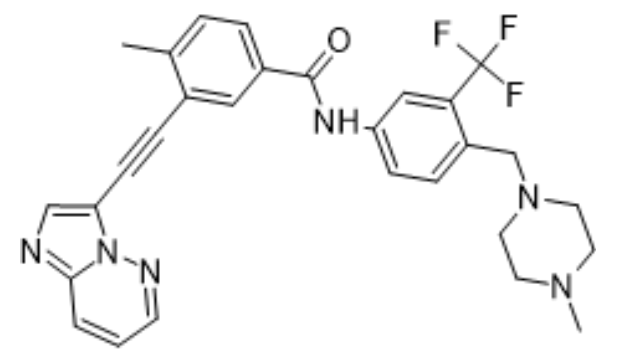

(2)

Figure 2: The chemical structure of Ponatinib.

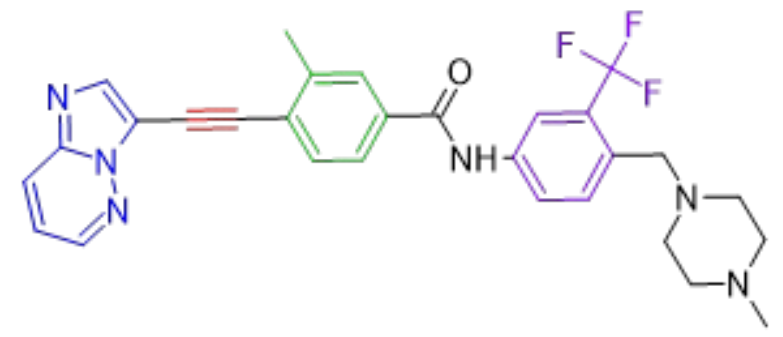

(2)

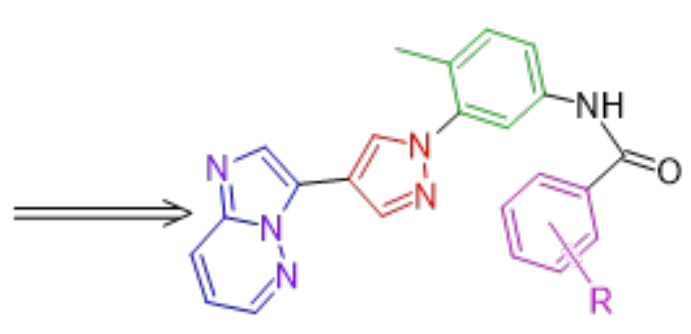

(3)

Figure 3: Pyrazole-containing IMP-phenylbenzamide derivatives (3) as inspired from ponatinib (2) Color coding: Blue $=$ head; red $=$ linker; green $=$ middle; violet $=$ tail.

\section{VEGF Receptor 2 Kinase Inhibitor}

Miyamoto and colleagues reported the design, synthesis, and biological evaluation of 2-acylamino6-phenoxy-IMP derivatives. Hybridization and optimization yielded the discovery of $\mathrm{N}-[5-(\{2-$ [(cyclopropylcarbonyl)amino]IMP-6-yl\}oxy)-2methylphenyl]-1,3-dimethyl-1H-pyrazole-5carboxamide (TAK-593) as a highly potent VEGF 
receptor 2 kinase inhibitor. TAK-593 applied a strong suppression to the proliferation of VEGFstimulated human umbilical vein endothelial cells. Kinase selectivity profiling showed an inhibition of platelet-derived growth factor receptor kinases as well as VEGF receptor kinases (34) (see Figure 5, Scheme 1, Scheme 2, Figure 6).

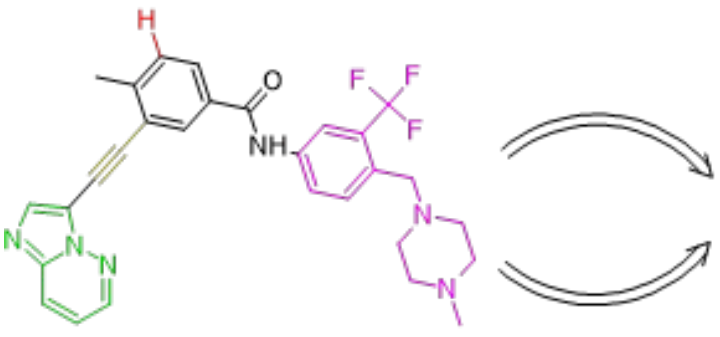

(2)

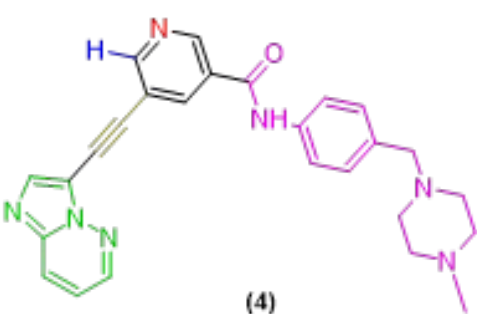

(4)

Figure 4: Modifications were made to Ponatinib and some new compounds emerged, with better performance.<smiles>O=C(Nc1cccc(Oc2ccc3nc(NC(=O)C4CCOCC4)cn3n2)c1)c1cccc(C(F)(F)F)c1</smiles>

(11)

Figure 5: Chemical structure of a hybrid compound developed.<smiles>[R]OC(=O)OCCC(C)C</smiles>

(12)

(13)

(14)

(15)<smiles>[R]C(=O)Nc1cn2nc(Oc3cccc(NC(=O)c4cccc(F)c4)c3)ccc2n1</smiles>

(16)

Scheme 1: Synthesis of compound (16). Reaction conditions: i) ethyl (chloroacetyl)carbamate, $\mathrm{Na}_{2} \mathrm{HPO}_{4}$, DMA; ii) $\mathrm{Ba}(\mathrm{OH})_{2}, \mathrm{NMP} / \mathrm{H}_{2} \mathrm{O}$; iii) $\mathrm{R}_{1} \mathrm{COCl}, \mathrm{DMA}$; iv) 3-aminophenol, $\mathrm{K}_{2} \mathrm{CO}_{3}, \mathrm{DMF}$; v) 3-fluorobenzoyl chloride, DMA. 


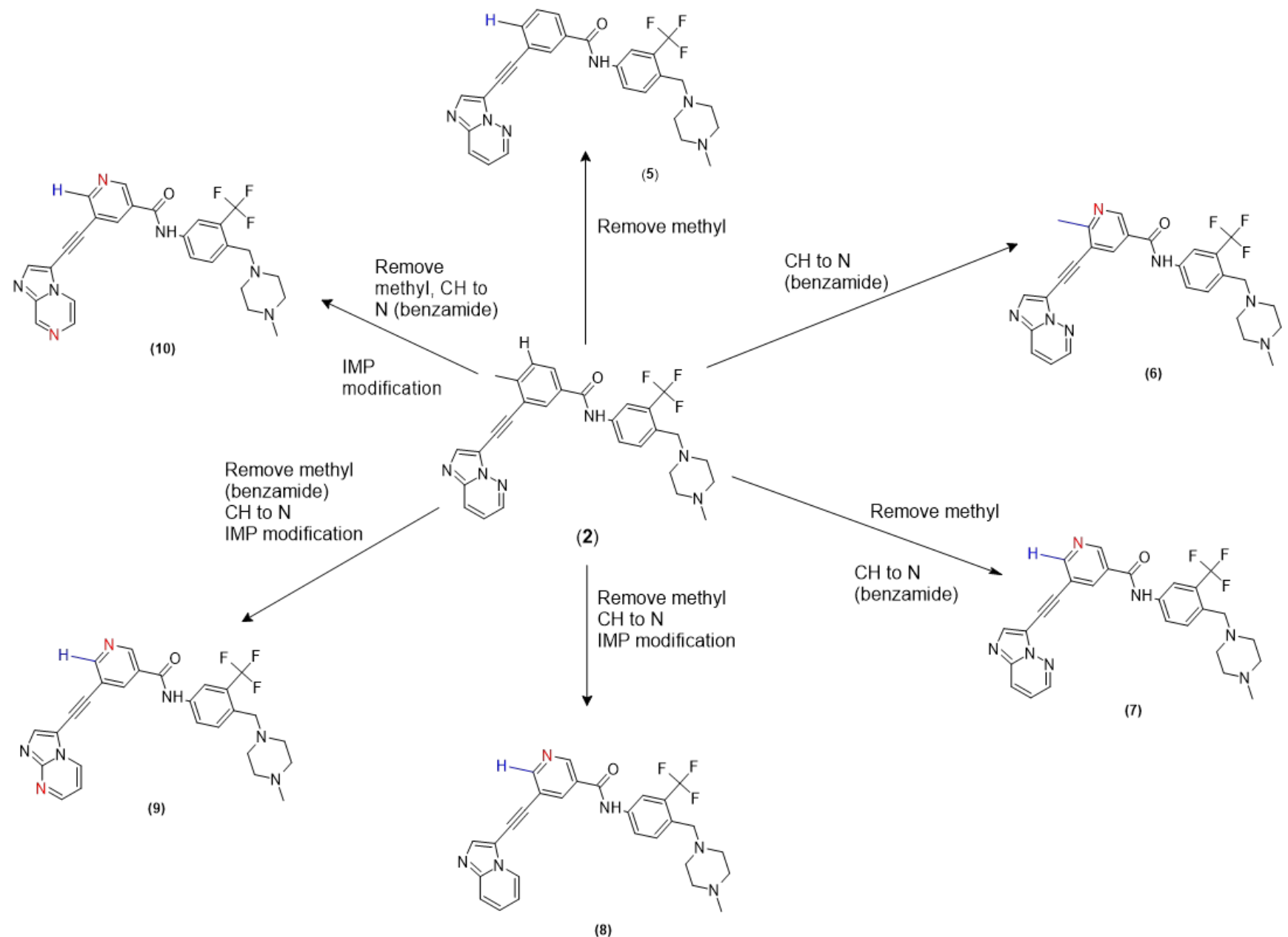

Scheme 2: Nitrogen scan of ponatinib.

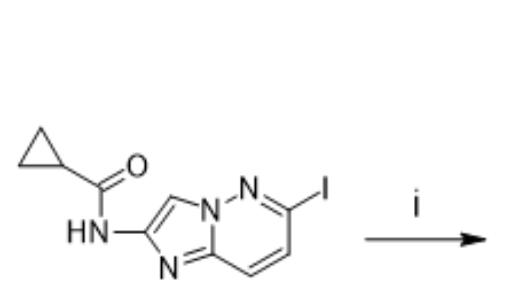

(13)

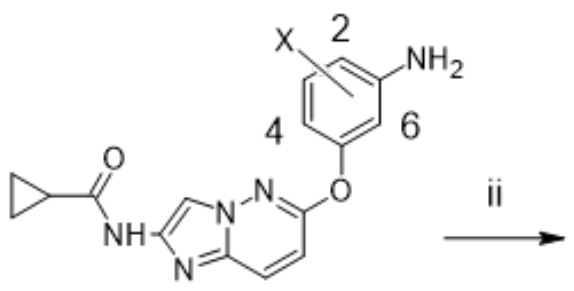

(14)<smiles>[Z]c1cc(NC(=O)c2cc(C)nn2C)cc(Oc2ccc3nc(NC(=O)C4CC4)cn3n2)c1</smiles>

(15)

Scheme 3: Modification of an easily found starting compound to obtain a highly potent derivative. Reaction conditions: i) aminophenols, $\mathrm{K}_{2} \mathrm{CO}_{3}$, DMF or 5-amino-2-methylphenol, $\mathrm{NaH}$, DMF; ii) 1,3-dimethyl- $1 \mathrm{H}$ pyrazole-5-carboxyl chloride, DMA or 1,3-dimethyl-1H-pyrazole-5-carboxyl chloride, triethylamine, THF, or 1,3-dimethyl-1H-pyrazole-5-carboxyl chloride, NMP.

\section{Inhibitors of TNF-a Production}

Tumor necrosis factor-alpha (TNF-a) is an important pro-inflammatory cytokine responsible for a diverse range of inflammatory diseases including rheumatoid arthritis. In their manuscript, Pandit et al. summarized the medicinal chemistry efforts on the design, synthesis and TNF-a evaluation of a series of 3,6-disubstituted imidazo[1,2-b]pyridazine (4) (see Figure 7, Figure 8, Scheme 4, Scheme 5).

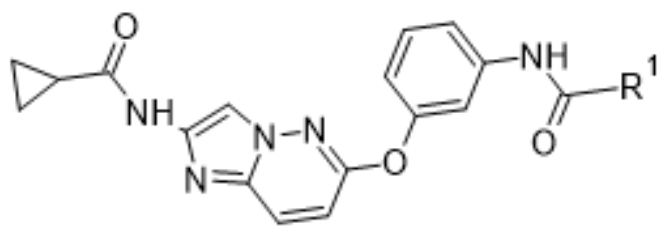

(12)

Figure 6: A series of compounds containing the IMP nucleus, having VEGFR2 binding ability. $\mathrm{R}^{1}=$ cyclopropyl, tert-butyl, pyridin-4-yl, 1,2-oxazol-5-yl, 3-methyl-1,2-oxazol-5-yl, 1-methyl-1,2,3-triazol-5- 
<smiles>O=C(NC[C@@H]1CC(F)CN1)c1ccc(-c2cnc3ccc(NC4CCC4)nn23)cc1F</smiles>

Ikk $\beta$ inhibitor<smiles>C[C@H](Nc1ccc2ncc(C3C=CC=NC3=O)n2n1)c1ccc(F)cn1</smiles>

Jak1, Jak2,

(21)<smiles></smiles>

Jak2 inhibitor

(22)

(23)

Figure 7: Some example molecules and their inhibitory activities.<smiles>[R]Oc1ccc2ncc(Br)n2n1</smiles>

Figure 8: Designed modifications on IMP scaffold. $R$ is alkyl or aryl.<smiles>Nc1ccc(Cl)nn1</smiles>

(25)

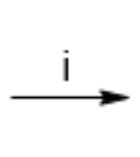<smiles>Clc1ccc2nccn2n1</smiles>

(26)

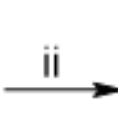<smiles>Clc1ccc2ncc(Br)n2n1</smiles><smiles>C#C[CH+]C</smiles>

(27)<smiles>[R]Oc1ccc2ncc(Br)n2n1</smiles>

(28)<smiles>[R]Oc1ccc2ncc(Br)n2n1</smiles>

(29)

Scheme 4: Synthetic procedure for some inhibitors, starting from a pyridazine derivative. Reagents and conditions: i) Chloroacetaldehyde dimethyl acetal, sodium acetate, concentrated $\mathrm{HCl}, 60 \%$ aqueous ethanol, reflux, overnight. ii) $\mathrm{NBS}, \mathrm{CHCl}_{3}, 25-30^{\circ} \mathrm{C}, 15$ min. iii) cyclopentylmethanol or cyclohexanol, $\mathrm{NaH}, \mathrm{THF}, 0$ ${ }^{\circ} \mathrm{C}$ to room temp, overnight. iv) $\mathrm{ArB}(\mathrm{OH})_{2} / \mathrm{ArB}(\mathrm{pin}), \mathrm{Pd}\left(\mathrm{PPh}_{3}\right)_{2} \mathrm{Cl}_{2}, \mathrm{~K}_{2} \mathrm{CO}_{3}, \mathrm{DMF}-\mathrm{H}_{2} \mathrm{O}$, microwave, $140{ }^{\circ} \mathrm{C}$, 0.5-1 h.<smiles>Clc1ccc2nccn2n1</smiles>

(30)<smiles>[R]c1ccc(Oc2ccc3nccn3n2)cc1</smiles>

(31)

Scheme 5: Part of the synthetic scheme, starting from chloro-IMP. Reaction conditions: $\mathrm{CuI}_{1} \mathrm{Cs}_{2} \mathrm{CO}_{3} \mathrm{DMF}$, $140{ }^{\circ} \mathrm{C}$. MW, 40-120 $\mathrm{min}$.

BTK Inhibitors for Autoimmune Diseases

As potential inhibitors for BTK, two imidazopyrazine derivatives were synthesized. The imidazopyrazine core was changed with an IMP moiety and it was reported that the replacement led to a better outcome (5) (see Figure 9). 


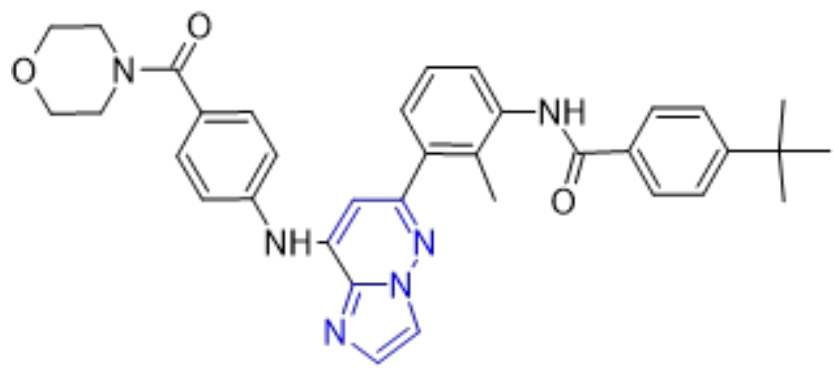

(32)

Figure 9: Heterocyclic replacement of the imidazo[1,2-a]pyrazine core with IMP.

Pyridazine Nucleus as an Active Ingredient of Anticancer Drugs

To have a more active and less toxic anticancer drug at hand is a mostly wanted asset. There are numerous pyridazine-containing anticancer drugs on the market, and the review by Zhang-Xu He and their colleagues shed light on their properties. It is reported that TAK-593 (compound $\mathbf{3 3}$ ) is in the first phase, targeted on VEGF and PDGF and clinically used on solid tumors (15) (See Figure 10).<smiles>Cc1cc(C(=O)Nc2cc(Oc3ccc4nc(NC(=O)C5CC5)cn4n3)ccc2C)n(C)n1</smiles>

(33)

Figure 10: Chemical structure of TAK 593.

\section{mTOR Inhibition by IMP Derivatives}

ATP-competitive mTOR (mammalian target of rapamycin) inhibitors have been studied as potential antitumor agents. A new class of IMP analogues were reported as potential mTOR inhibitors, in which structural modifications were focused on positions 3 , 6,8 of IMP skeleton. The promising compound 34 (see Figure 12) had a strong antitumor activity toward A549 cells, and bind to mTOR kinases. Guided by the principle of scaffold hopping, Chen and co-authors developed a novel class of IMP derivatives simplified as $\mathbf{3 5}$ as potent IRAK4 (interleukin-1 receptor associated kinase 4) inhibitors (see Figure 12). Above results confirmed that pyridazine-based $\mathbf{3 5}$ could be a potent IRAK4 inhibitor and worthy of further exploration for the treatment of mutant MYD88 DLBCL (15). A series of IMP derivatives were prepared as competitive inhibitors of ATP mTOR. Compound $\mathbf{3 4}$ and its isomer $\mathbf{3 5}$ in which the pyridine nitrogen is placed at the 4 position below were reviewed among other compounds (6). A promising compound, 36, is considered to be a potent compound. Scaffold hopping of $\mathbf{3 7}$ to $\mathbf{3 8}$ produces a good substance (15).

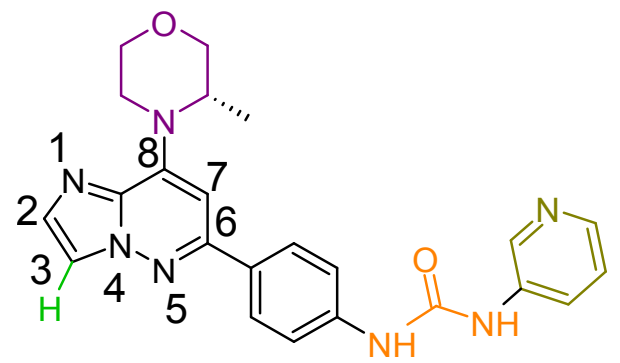

(34)<smiles></smiles>

(35)

Figure 11: Regions of activity for an IMP molecule under design. For substitution of IMP at position 8 (magenta), (S)-3-methylmorpholine > morpholine > 8-oxa-3-azabicyclo[3.2.1]octane. For the hydrogen at position 3 (green), $\mathrm{H}>\mathrm{Me}>\mathrm{Et}$. The ureudo group provides improved activity. As for the olive-colored area on the right, pyridyl is greater than phenyl. Also, the pyridine nitrogen's position was tested. 


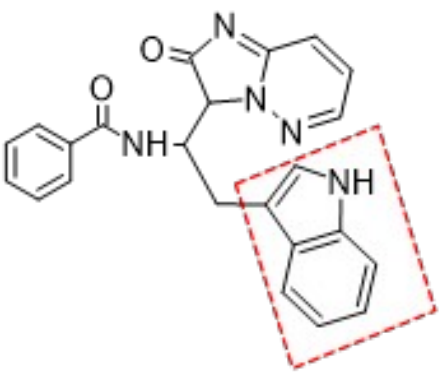

(36)<smiles>C[C@@]1(CO)Cc2cc(NC(=O)c3cnc4cccnn34)c(N3CCOCC3)cc2O1</smiles>

(37)<smiles>[R]c1n[nH]c([R])c1NC(=O)c1cnc2ccc(N[C@@H]3CCCNC3)nn12</smiles>

(38)

Figure 12: A promising compound $\mathbf{3 6}$ (left). Scaffold hopping of compound $\mathbf{3 7}$ in the middle, which is an IRAK inhibitor, produces the compound $\mathbf{3 8}$ on the right ( $R_{1}$ is methyl, cyano, difluoromethyl, carbamoyl and

\section{Anticancer Activity}

$\mathrm{R}_{2}$ is methyl, ethyl, isopropyl, 4-piperidyl, and 4-THP).

Shen and coworkers studied about indolizine derivatives, and reported the successful anticancer activity of some of them. Some compounds contained IMP nucleus, the structures are given in Scheme 6 and Scheme 7 (35). An Indian research group prepared 1,2,4-thiazole-substituted IMP molecules for a possible anticancer activity. The cancer types investigated were breast (MCF-7, MDA MB-231), lung (A549), and prostate (DU-145) with MTT assay. Five of the compounds prepared were found to be potent against the cancer types, especially one of them was found to possess the most promising anticancer activity (Scheme 8) (36).
Tewari and coworkers have filed a patent in which IMP was present in a structure called Cefozopran (46, see Figure 13) (37).

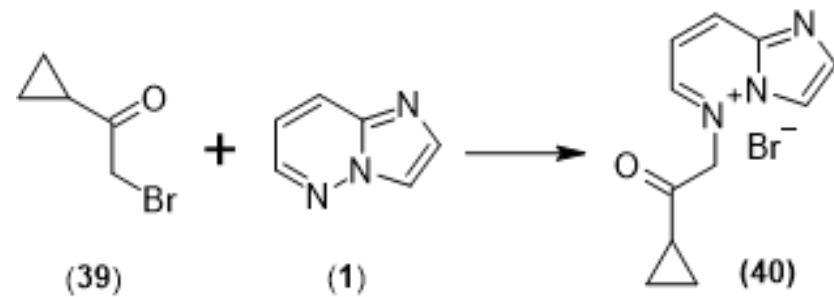

Scheme 6: Alkylation of IMP from the nitrogen at position 5 .

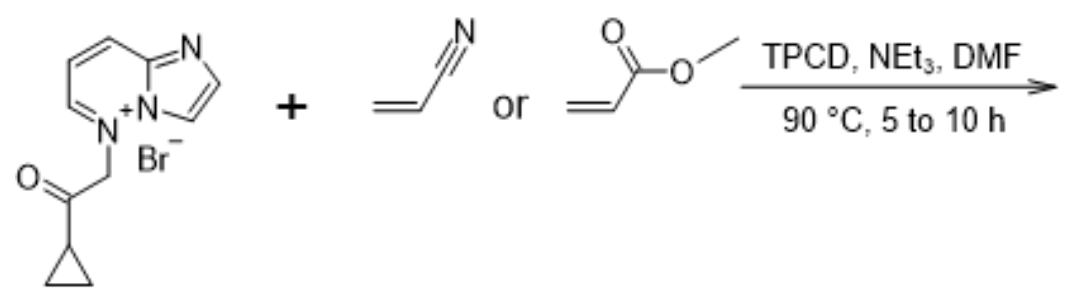

(41)
(42)<smiles></smiles>

(44)<smiles></smiles>

(45)

Scheme 7: Synthesis of indolizine derivatives from the cationic IMP starting material. TPCD is tetrakis(pyridine)cobalt(II) dichromate, an oxidizing material.<smiles>CO/N=C(\C(=O)N[C@H]1C(=O)N2C=C(C[n+]3ccn4ncccc43)CS[C@H]12)c1nsc(N)n1</smiles>

(46)

Figure 13: Chemical structure of Cefozopran. 


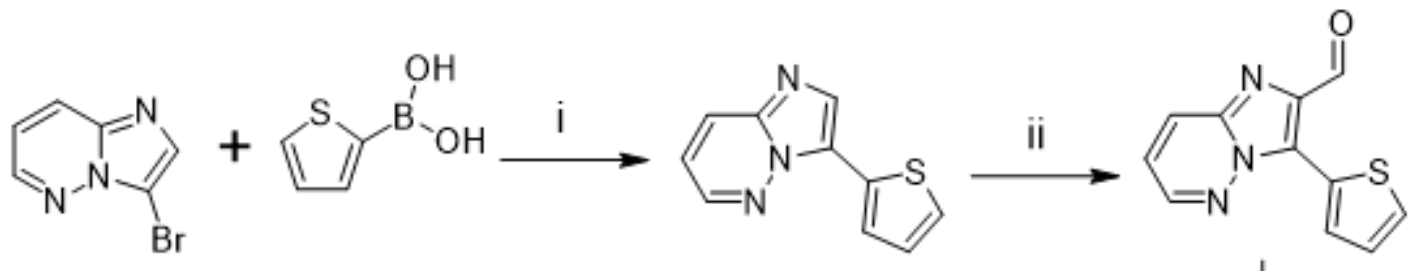

(47)

(48)<smiles>c1ccc(-c2nsc(-c3nc4cccnn4c3-c3cccs3)n2)cc1</smiles>

(53)
(49)<smiles>C=C(N)c1nc2cccnn2c1-c1cccs1</smiles>

(52)
(50)

Scheme 8: Functionalization of the IMP starting compound, 47. Reaction conditions: i) $\mathrm{Pd}\left(\mathrm{PPh}_{3}\right)_{4}, \mathrm{Cs}_{2} \mathrm{CO}_{3}$, DMA, $80^{\circ} \mathrm{C}, 21 \mathrm{~h}$. ii) $\mathrm{HMTA}, \mathrm{AcOH}, \mathrm{H}_{2} \mathrm{O}$, reflux, $12 \mathrm{~h}$. iii) $\mathrm{NH}_{2} \mathrm{OH} . \mathrm{HCl}$, DMSO, $90{ }^{\circ} \mathrm{C}, 2 \mathrm{~h}$. iv) $\mathrm{NaSH}$, $\mathrm{MgCl}_{2} .6 \mathrm{H}_{2} \mathrm{O}, \mathrm{DMF}, 40{ }^{\circ} \mathrm{C}, 90$ min. v) Substituted cyanobenzenes, $\mathrm{AlCl}_{3}, \mathrm{n}-\mathrm{BuOAC}, 70^{\circ} \mathrm{C}, 5 \mathrm{~h}$. The final compound has the following substitutents at the benzene ring: $\mathrm{H}, 3,4,5$-trimethoxy, 3,5-dimethoxy, 4methoxy, 4-chloro, 4-bromo, 4-nitro, 3,5-dinitro, 4-methyl, and 4-(dimethylamino).

\section{PDE 10A Inhibition}

A review article by Jankowska et al. in 2019 provides deep information about PDE10A and what has recently been done about the design of selective PDE10A inhibitors. Schizophrenia, Huntington's, and Parkinson's diseases are central nervous systemrelated disorders and treatment of them with PDE10A inhibitors are discussed (38).

\section{Inhibition of Aurora B Kinases}

Juillet and colleagues tried to vary the flexibility of the molecules and first replaced the acetylene linker with an alkene moiety. The preparation of the alkene series is depicted in Scheme 9 (39).

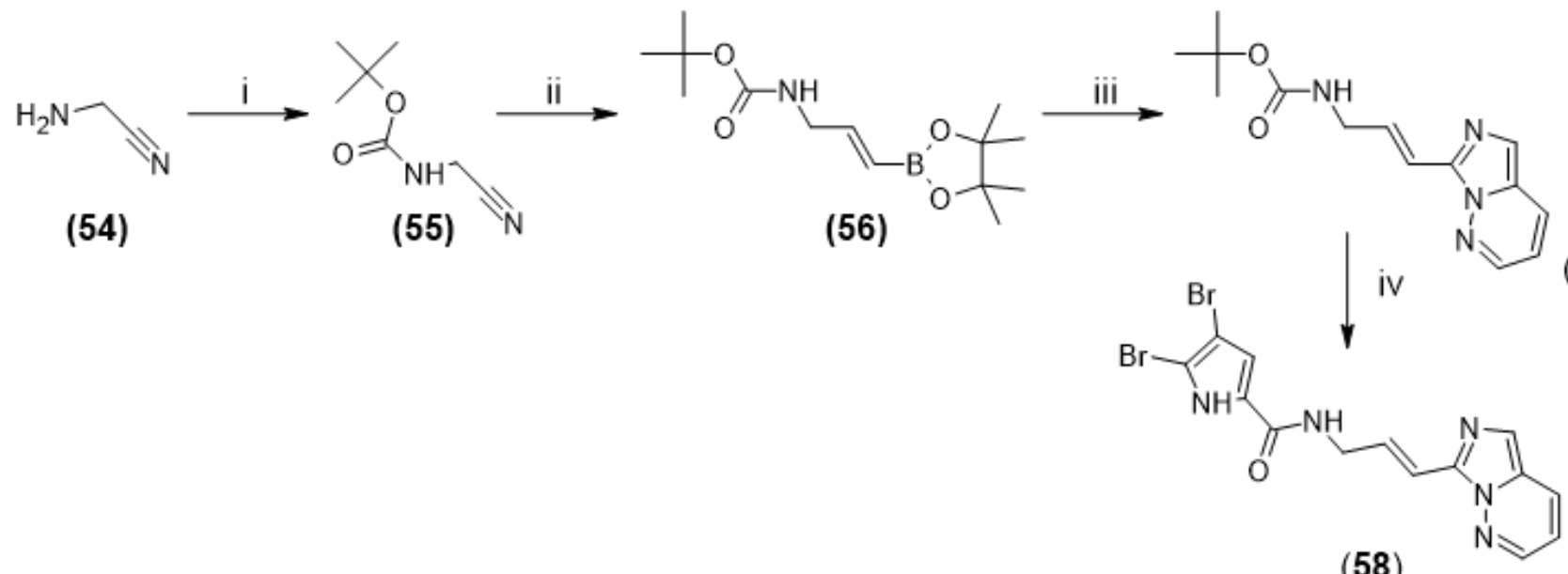

Scheme 9: Formation of the IMP nucleus, among other compounds, and addition of a dibromopyrrole to the side. Reagents and conditions: i) (Boc) $\left.)_{2} \mathrm{O}, \mathrm{DMAP}, \mathrm{DCM} . \mathrm{ii}\right)$ pinacolborane, $\mathrm{Cp}_{2} \mathrm{ZrHCl} 25 \mathrm{~mol}^{2}, \mathrm{Et}_{3} \mathrm{~N}, 25 \mathrm{~mol}$ $\%, 40{ }^{\circ} \mathrm{C}$. iii) $\mathrm{R}-\mathrm{I}, \mathrm{Pd}\left(\mathrm{PPh}_{3}\right)_{4}, 5 \mathrm{~mol} \%, \mathrm{~K}_{2} \mathrm{CO}_{3}(2 \mathrm{M})$, dioxane, $80{ }^{\circ} \mathrm{C}$. iv) $4 \mathrm{~N} \mathrm{HCl}$, then trichloroacetyl dibromopyrrole.

\section{Activin Receptor-Like Kinase 2 (R206H) Inhibition \\ Classic FOP (fibrodysplasia ossificans progressiva) is caused by the $\mathrm{R} 206 \mathrm{H}$ mutation in ALK2/ACVR1. There are many activin receptor-like kinase 2 (ALK2) inhibitors which are effective in animal models of this disease, however most of the ALK2}

$(\mathrm{R} 206 \mathrm{H})$ inhibitors did not have an adequate oral bioavailability to be efficient. In the study, there were 12 ALK2 (R206H) inhibitors selected for the best performance, in which an IMP derivative was found to work efficiently (see Figure 14) (8). 
<smiles>c1cnn2c(-c3ccc4c(c3)CCO4)cnc2c1</smiles>

(59)<smiles>OC1CCC(Nc2ccc3ncc(Br)n3n2)CC1</smiles>

(60)
Figure 14: Two ALK2 (R206H) inhibitors based on IMP skeleton.

\section{PIM Kinase Inhibitors}

IMP was considered as a new PIM $-1 / 2$ inhibitor. Preliminary SAR studies at C3 and C6 positions of the heterocycle yielded three inhibitors. Further SAR studies of IMP were reported in the Supergen patent and the structure of SGI-1776 was disclosed (see Figure 15). SGI-1776 was the first clinically evaluated PIM inhibitor in patients with relapsed and/or refractory leukemias. It was unfortunate that the clinical assessment of this molecule was terminated, since its affinity to inhibit the ether-ago-go-related gene (hERG) channel resulted in cardiac toxicity. Nevertheless, efforts are continuing with identification of potent and selective PIM -1 inhibitor TP-3654 without hERG or cytochrome P450 inhibition. In current, TP-3654 is under clinical assessment in patients having advanced solid tumors (See Figure 15) (9). Shannan and co- workers reported about SGI-1776, which has previously been investigated in patients. SGI-1776 is reported to inhibit all three PIM kinases. When this pan-PIM kinase inhibitor was treated with AML xenografts, concentration-dependent tumor regressions were previously shown; therefore, they investigated the different preclinical models of melanoma of this drug. AlamarBlue assay, when combined with adherent melanoma cultures, let the researchers observe that SGI 1776 possessed inhibitory effects similar to SM200, melanoma cell lines were mostly inhibited, but not normal fibroblasts. At $10 \mu \mathrm{M}$ concentration, SGI-1776 increased cell death significantly in the melanoma cell lines when compared to normal fibroblasts. They used propidium iodide staining (40). Moloney leukemia virus (PIM) kinases are serine/threonine kinases and they are present in many important cancer cell signaling pathways. The research group evaluated PIM expression in low- and high-grade urothelial carcinoma cases and assessed the role of PIM in the progression of disease and their potential to serve as molecular therapeutic targets. A total of 137 cases were investigated. All three PIM family members were highly expressed in non-invasive and invasive urothelial carcinoma cases. A bladder cancer case was subjected to a in vivo xenograft study and it was found that PIM kinase inhibition led to a reduction in tumor growth; therefore PIM kinase inhibitors may be active players in human urothelial carcinomas (41).

\section{Substitutions at 5 and 8 are not tolerated}<smiles>[R2]Nc1ccc2ncc([R7])n2n1</smiles>

(62)

Figure 15: Development of SGI-1776 and TP-3654.

\section{Death-Associated Protein Kinase (DAPK) Inhibitors}

Many compounds have been reported as DAPK inhibitors, including aminopyridazine and IMP (See Figure 16) (10). 
<smiles>COc1cc(-c2ccc3ncc(-c4cccc(C(=O)NCCN(C)C)c4)n3n2)ccc1O</smiles>

(64)<smiles></smiles>

(65)<smiles></smiles>

(66)

Figure 16: As DAPK1 inhibitors, three IMP derivatives were prepared. Molecule 64 shows that red color is the hydrophobic pocket-binding core, and blue color depicts the hinge-binding core.

\section{Glycogen Synthase Kinase-3 Inhibition}

IMP substitution at the R2 position in $\mathbf{4 3}$ gave the lowest IC50 values for the series of other compounds (see Figure 17) (11).<smiles>O=C1NC(=O)C(C2CN3CCN(C(=O)N4CCNCC4)Cc4cccc2c43)=C1c1cn2ncccc2n1</smiles>

Radioligands for Tropomyosin Receptor Kinase Family

Tropomyosin receptor kinases family (TrkA, TrkB, and TrkC) represent adult life and aging, and when they downregulate, diseases like Alzheimer's emerge. In addition, overexpressed or abnormally expressed TrkA/B/C proteins point to neurogenic or non-neurogenic human cancers and they are under intensive clinical research. Small molecule kinase catalytic domain binding inhibitors were selected for ${ }^{11} \mathrm{C}$ and ${ }^{18} \mathrm{~F}$ positron electron tomography (PET, see Figure 18, Figure 19) (18).

(67)

Figure 17: An IMP-containing molecule, having advantageous properties.<smiles>CNC(=O)c1cnc2ccc(N3CCC[C@H]3c3cccc(F)c3)nn12</smiles>

(68)<smiles>O=C(NC1CC(F)C1)c1cnc2ccc(N3CCC[C@H]3c3cccc(F)c3)nn12</smiles>

(69)<smiles>O=C(Nc1ccc(CC[18F])cc1)c1cnc2ccc(N3CCC[C@H]3c3cccc(F)c3)nn12</smiles>

(70)<smiles>COc1ccc(NC(=O)c2cnc3ccc(N4CCC[C@H]4c4cccc(F)c4)nn23)cc1F</smiles>

(71)

Figure 18: Chemical structures of precilinical IMP-based Trk-targeted PET radioligands. 
<smiles>COc1ccc(NC(=O)c2cnc3ccc(N4CCC[C@H]4c4cccc(F)c4)nn23)cc1F</smiles>

(72)<smiles>O=C(Nc1ccc(F)cc1)c1cnc2ccc(N3CCC[C@H]3c3cccc(F)c3)nn12</smiles>

(73)

Figure 19: Chemical structures of clinical IMP-based Trk-targeted PET radioligands.

\section{Using IMP's FGFR1 Activity in Another Class of Heterocyclic Compound}

A research group in China wanted to synthesize a new class of pyrrolo[2,3-b]pyrazine, and to use the $\Pi-\Pi$ stacking interaction of an IMP derivative with residue Phe489 of the protein, they decided to preserve this interaction and, they also simplified the synthetic procedure. They used the IMP skeleton to see the Fibroblast Growth Factor Receptor 1 (FGFR1) enzymatic activity. IMP was sulfonated and chlorinated to make it ready to couple to the pyrazine structure (see Figure 20) (12).<smiles>COc1cc(OC)c(Cl)c(CCc2cnc3ccn(S(=O)(=O)c4cnc5cccnn45)c3n2)c1Cl</smiles>

(74)

Figure 20: An IMP-based compound tested for FGFR1 activity.

\section{Inhibitors for Dengue Fever}

Dengue virus (DENV) is an arboviral human pathogen transmitted through mosquito bite that infects, annually, an estimated circa 400 million humans (about 5 percent of the global population). No therapeutic agents have currently been developed for prevention or treatment of the infections owing to this pathogen. IMP is an inhibitor of AAK1 and GAK pathways that inhibit DENV replication (13).

\section{Inhibitors for Tyrosine Kinase 2}

An IMP derivative underwent modifications to yield a molecule, which showed good functional potency and its kinase selectivity was excellent, yet its metabolic stability was poor, pharmacokinetic properties (in mouse) were modest, and phosphodiesterase 4 (PDE4) activity was in a medium state (42). As a member of the Janus (JAK) family of non-receptor tyrosine kinases, TYK2 mediates the signaling of pro-inflammatory cytokines including IL-12, IL-23 and type 1 interferon (IFN), and therefore represents an attractive potential target for treating the various immuno-inflammatory diseases in which these cytokines have been shown to play a role. IMP was identified as a promising hit compound. Iterative modification was exercised for each of the substituents of the IMP scaffold, and the cellular potency was improved, selectivity was maintained over the JH1 domain (see Figure 21, Scheme 10, Scheme 11) (43).<smiles>N#Cc1cc(Nc2cc(NC3CC3)c3ncc(C(N)=O)n3n2)cc(C(F)(F)F)c1</smiles>

(75)<smiles>CNc1cc(Nc2cc(F)cc(F)c2OC)nn2c(C(=O)NCC(C)(O)CO)cnc12</smiles>

(76)

Figure 21: Previously reported TYK2 JH2 ligands. 


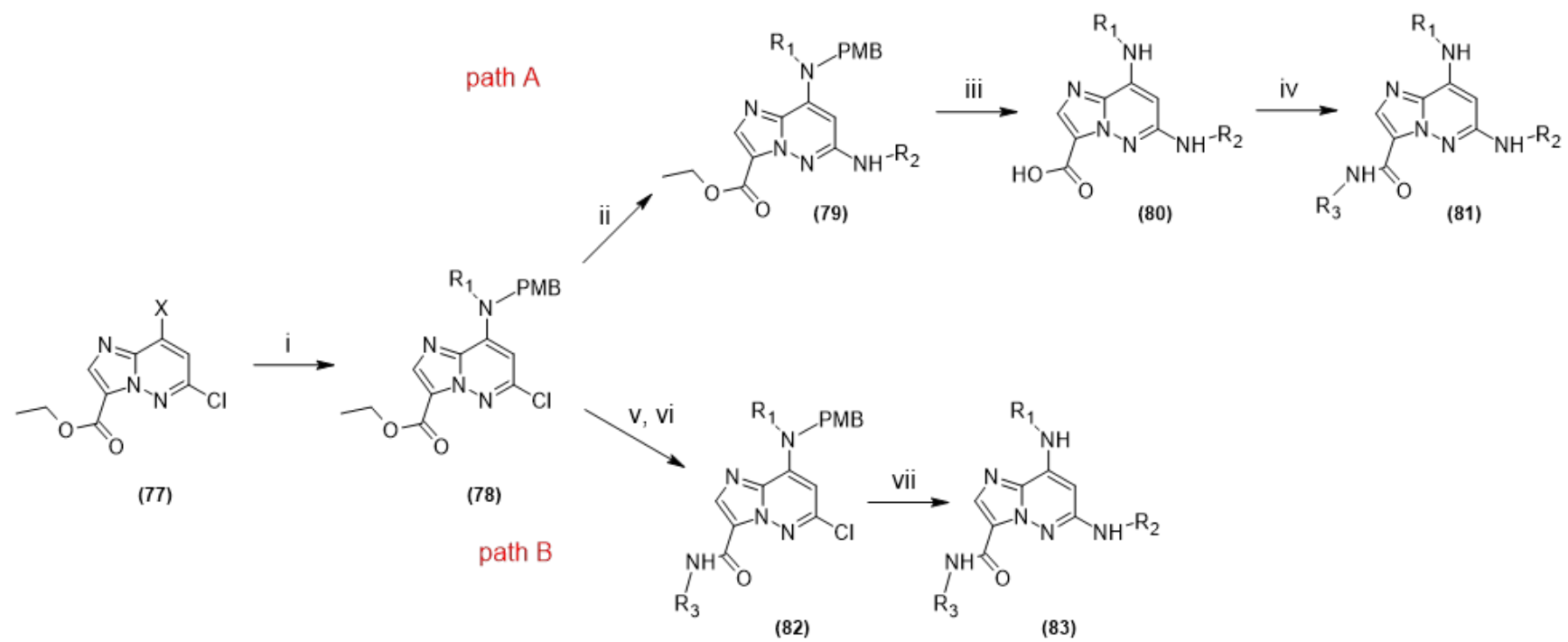

Scheme 10: Synthesis of TYK2 JH2 ligands with two different paths. Reaction conditions: i) $\mathrm{R}^{1}-\mathrm{NH}-\mathrm{PNB}$, $\mathrm{NEt}_{3}, 1$,4-dioxane, $90{ }^{\circ} \mathrm{C}$, ii) $\mathrm{H}_{2} \mathrm{NR}_{2}, \mathrm{Pd}_{2} \mathrm{dba}_{3}$, Xantphos, $\mathrm{Cs}_{2} \mathrm{CO}_{3}, \mathrm{DMA}, 100{ }^{\circ} \mathrm{C}$, iii) a- $\mathrm{HCl}$, dioxane, RT, b$\mathrm{NaOH}, \mathrm{MeOH}, \mathrm{H}_{2} \mathrm{O}$, iv) HATU; $\mathrm{H}_{2} \mathrm{NR}_{3}, \mathrm{DMF}, \mathrm{N}$-methylmorpholine, RT, v) LiOH, MeOH, THF, $\left.\mathrm{H}_{2} \mathrm{O}, \mathrm{RT}, \mathrm{vi}\right)$ $\mathrm{NH}_{2} \mathrm{R}_{3}, \mathrm{BOP}$, iPr${ }_{2} \mathrm{NEt}, \mathrm{DMF}$, vii) a- $\mathrm{H}_{2} \mathrm{NR}_{2}, \mathrm{Pd}_{2} \mathrm{dba}_{3}$, Xantphos, $\mathrm{Cs}_{2} \mathrm{CO}_{3}, \mathrm{DMA}, 125{ }^{\circ} \mathrm{C}, \mathrm{b}-\mathrm{HCl}$ (4 $\mathrm{M}$, in dioxane), DCM, RT.<smiles>[R]Nc1cc(Nc2cc(C)cc(C)c2)nn2c(C(N)=O)cnc12</smiles>

Scheme 11: The synthesis for allowing late stage examination of the C8 group, utilizing a thiol group to block this position.

\section{Calcium-Dependent} Toxoplasma gondii

For toxoplasmosis, the currently available tools are drugs that are non-specific to the parasite and cause serious side effects. There is an urgent need of development of anti-Toxoplasma compounds that have higher efficiency and that are more specific to it. IMP derivatives were designed to inhibit the Toxoplasma gondii's calcium-dependent protein kinase 1 (TgCDPK1) and they were effective against 
tachzoite growth in vitro. The authors stress that IMP salts are strongly efficient, in vivo, on acute taxoplasmosis and that a mouse congenital taxoplasmosis model should be set up for further testing (14).

\section{Steraoyl-CoA Desaturase (SCD)}

A number of patents about small molecule inhibitors of SCD-1 have been published. As an example, many patents describe related piperazine-based inhibitors of SCD-1 (like Figure 22, 90). As an interesting note, the diazine-amide portion of compound 89 (Figure 22) can be mimicked by IMP in compound 90. Presently, work in this field is known to be at the pre-clinical stage (see Figure 22) (44).<smiles>O=C(NCCC1CC1)c1ccc(N2CCN(C(=O)c3cc(Cl)ccc3Cl)CC2)nn1</smiles>

(89)<smiles>CCCCCc1cn2nc(N3CCN(C(=O)c4ccccc4C(F)(F)F)CC3)ccc2n1</smiles>

(90)

Figure 22: A small molecule SCD inhibitor (89) and its IMP derivative (90).

\section{Antimicrobial and Antimalarial Activity}

A series of 1-oxacephem analog compounds were prepared and their antibacterial properties against five Gram-positive and Gram-negative bacterial strains were evaluated in vitro. Ceftazidine was selected as the control. Some compounds contained IMP nucleus, and their structures are given below (see Figure 23) (45).<smiles>[R]SCC(=O)N[C@]1(OC)C(=O)N2C(C(=O)O)=C(C[n+]3cccc4nccn43)CO[C@H]21</smiles>

(91)

Figure 23: 1-Oxacephem derivative, having an IMP skeleton on side. $\mathrm{R}_{1}$ is difluoromethyl, 2chlorophenyl, or 2,5-dichlorophenyl.

\section{Antiparasitic Activity}

Despite being a small molecule, 3-nitro-6oxopropyl-IMP was considered for clinical trials (16).

\section{Antiproliferative Agents}

Sruthi and co-workers devised a synthetic method in which they obtained the IMP-2-one derivatives with a simple synthetic method. Then, they studied the in silico and in vitro activity against human cancer cell lines A375 and Colo-205, using MTT assay. Two of the synthesized compounds showed high antiproliferative activity and some of the other compounds displayed significant activity. All tested compounds were reported to be druggable and were free from toxicity and teratogenecity (see Scheme 12) (17). 


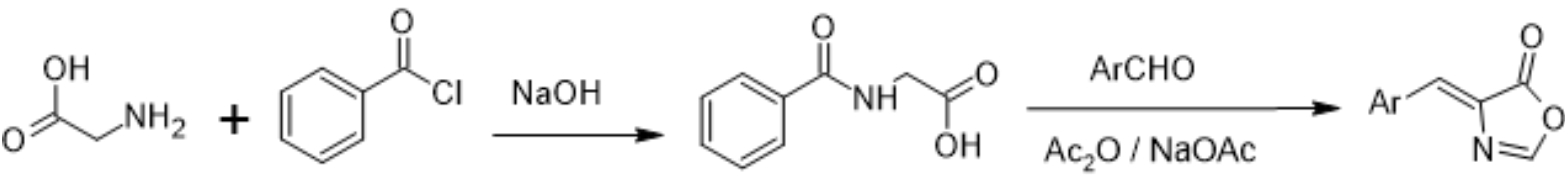

(92)

(93)

(94)

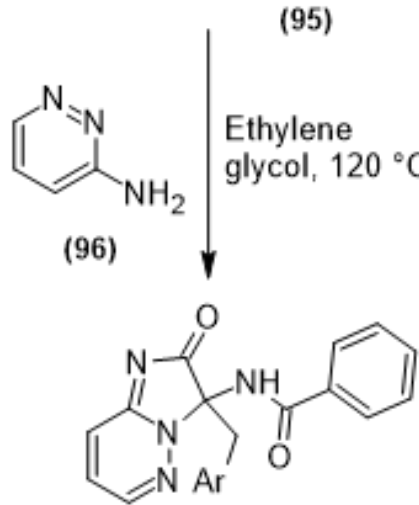

(97)

Scheme 12: Synthesis of benzamido-substituted IMP-2-one derivatives. $R$ is benzene, chlorophenyl, bromophenyl, 4-hydroxyphenyl, 3-hydroxyphenyl, 4-methylphenyl, 4-methoxyphenyl, 4-aminophenyl, 1naphthyl, $1 \mathrm{H}$-pyrrol-2-yl, pyridin-2-yl, furan-2-yl, $1 \mathrm{H}$-benzimidazol-3-yl, and 5-bromo-1H-benzimidazol-3yl.

\section{REVIEWS ABOUT SIMILAR MOLECULES}

The synthesis and properties of organic compounds with anticonvulsant properties have been reviewed by Özbek and Gürdere (46). The same authors published in Phosphorus, Sulfur and Silicon and Related Elements in 2021 about 2-aminothiazole derivatives for their anticancer properties. They state in their article that medicinal chemists and drug discovery researchers widely prefer 2aminothiazole moiety to adjust pharmacokinetic and pharmacodynamic properties of different molecules (47).

\section{SYNTHETIC WORKS}

The Historical Synthesis of IMP Derivatives

Branko Stanovnik and his colleagues reported the first instance of IMP chemistry in Tetrahedron in 1967. A year later, the same group published, in Tetrahedron again, about further synthetic modifications of the IMP nucleus (see Scheme 13, Scheme 14, Scheme 15, Scheme 16) $(1,48)$. Many research groups still rely on these historical documents about the synthesis of IMP derivatives. Austrian and Yugoslavian groups joined forces about synthesizing new pyridazine-containing heterocycles and a series of IMP derivatives were also prepared (see Scheme 17, Scheme 18, Figure 24) (49). 
<smiles>Nc1ccc(Cl)nn1</smiles>

(98)<smiles>Clc1ccc2nccn2n1</smiles>

(99)<smiles>C=C(C)Sc1ccc2nccn2n1</smiles><smiles>NNc1ccc2nccn2n1</smiles>

(101)
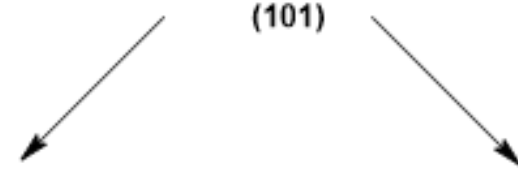<smiles>[R]Nc1ccc2nccn2n1</smiles>

(102)<smiles>c1cn2c(ccc3nncn32)n1</smiles>

Scheme 13: Formation of 6-chloro-IMP from 3-amino-6-chloropyridazine, and synthesis of 6phenylsulfanyl-IMP and 6-hydrazinyl-IMP molecules. The latter can be reacted to give Schiff's bases or cyclized to give another heterocycle.<smiles>[R]NC(=S)NNc1ccc2nccn2n1</smiles>

(107)

Scheme 14: Reactions of hydrazino-substituted IMP skeleton; thiosemicarbazide, dithiocarbamate, and by ring closure, thio-substituted heterocycle can be obtained. 
Akkurt B. JOTCSA. 2021; 8(4): 1217-1250.<smiles>Nc1ccc(Cl)nn1</smiles>

(98)

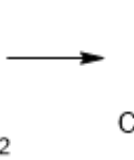<smiles>C1CCCC1</smiles>

$(99)$

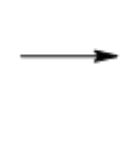

99)<smiles>c1ccc(Sc2ccc3nccn3n2)cc1</smiles><smiles>NNc1ccc2nccn2n1</smiles>

(101)

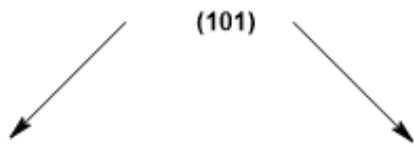<smiles></smiles><smiles>c1cn2c(ccc3nncn32)n1</smiles>

Scheme 15: Functional group conversions and cyclizations of IMP nucleus.<smiles></smiles>

(117)<smiles>[N-]=[N+]=Nc1ccc2nccn2n1</smiles><smiles>Nc1ccc2nccn2n1</smiles>

(120)

Scheme 16: Reactions of the hydrazide derivative. Formation of triazido, amino, and tetrazolo-IMP derivatives are depicted.

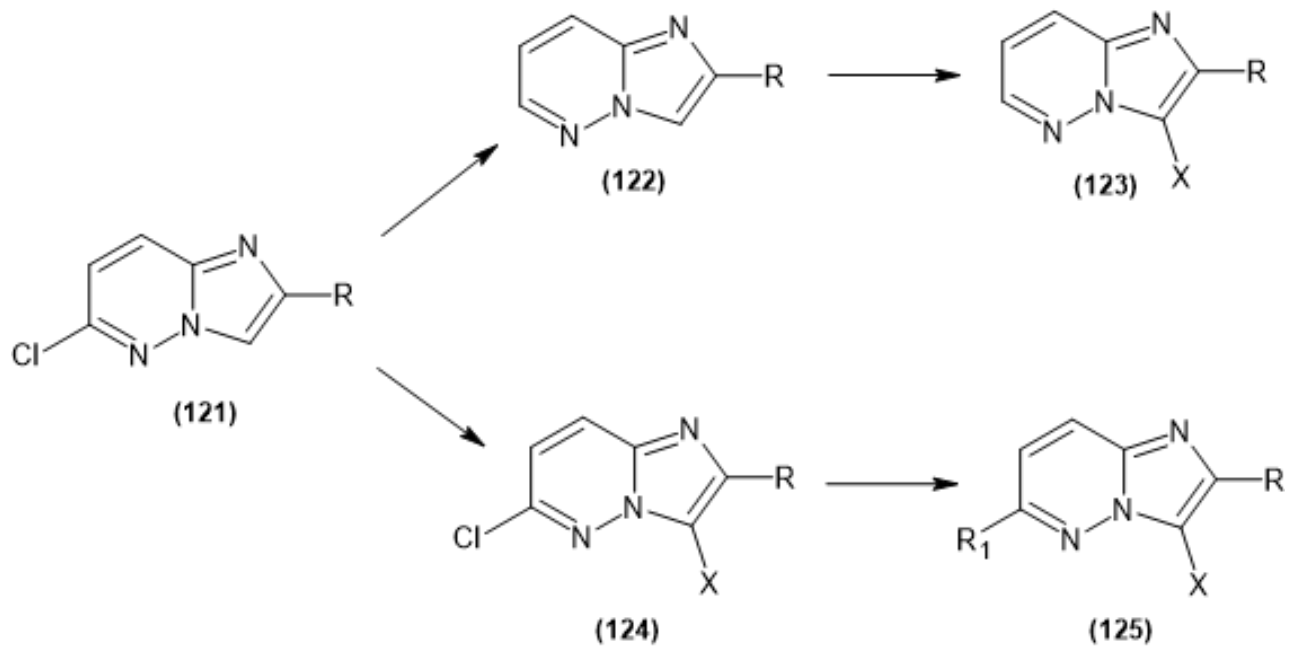

(124)

(125)<smiles>c1cn2c(ccc3nnnn32)n1</smiles>

(119)

Scheme 17: Starting from 6-chloro-IMP (a), dehalogenation was effected $(\mathbf{1 2 2}, R=H)$. Also, the molecule is easily brominated (123, $125 ; \mathrm{X}=\mathrm{Br}$ ). The chloro group could be substituted for hydrazine (125). 
<smiles>CCOC(=O)c1c(C)nc2ccc(Cl)nn12</smiles>

(126)<smiles>Cc1cc2nccn2nc1Cl</smiles>

(130)<smiles>Cc1nc2ccc(Cl)nn2c1C(=O)O</smiles>

(127)<smiles>Cc1cc(Cl)nn2ccnc12</smiles>

(131)<smiles>CCOC(=O)c1c(C)nc2ccc(OC)nn12</smiles>

(128)<smiles>Cc1cnn2ccnc2c1</smiles>

(132)<smiles>Cc1cn2nc(Cl)ccc2n1</smiles>

(129)<smiles>Cc1ccnn2ccnc12</smiles>

(133)

Figure 24: Synthesized IMP derivatives.<smiles>COC(=O)c1cnn2ccnc2c1C(=O)OC</smiles>

(1)

(134)

(135)

Scheme 18: Attack of methyl ester of carboxy radical to form 7,8-bis(carboxymethyl ester)-substituted IMP derivative.

\section{Multistep Synthesis of IMP Derivatives}

Methicillin- resistant Staphylococcus aureus (MRSA) required a modification in the related molecule, to be 2-(5-amino-1,2,4-thiadiazol-3-yl)-2(2)hydroxyimino acetyl group at the $\mathrm{C}-7$ position and a 3- or 6-substituted IMP-ium or 5-substituted imidazo[1,2-a]pyridinium group at the C-3' position. Among the novel derivatives, 3-(6-amino-IMP-ium1-yl)methyl-7ß-[2-(5-amino-1,2,4-thiadiazol-3-yl)2(Z)-hydroxyiminoacetamido]-3-cephem-4carboxylate showed an excellent balance of activity against MRSA and Gram-negative bacteria (see Scheme 19, Scheme 21, Scheme 20, Scheme 22) (50). Possible antitumor efficacy for various human cancers led to the synthesis of compounds as inhibitors for c-mesenchymal epithelial transition factor (c-Met) and vascular endothelial growth factor receptor 2 (VEGFR2) kinases. Parasubstituted inhibitors were prepared, by using known inhibitors with co-crystal structural information from c-Met and VEGFR2 in the complex structure (see Figure 25) (51).<smiles>CO/N=C(\C(=O)Cl)c1nsc(N)n1</smiles>

Scheme 19: Reaction of a protected thiadiazole and an IMP molecule. 


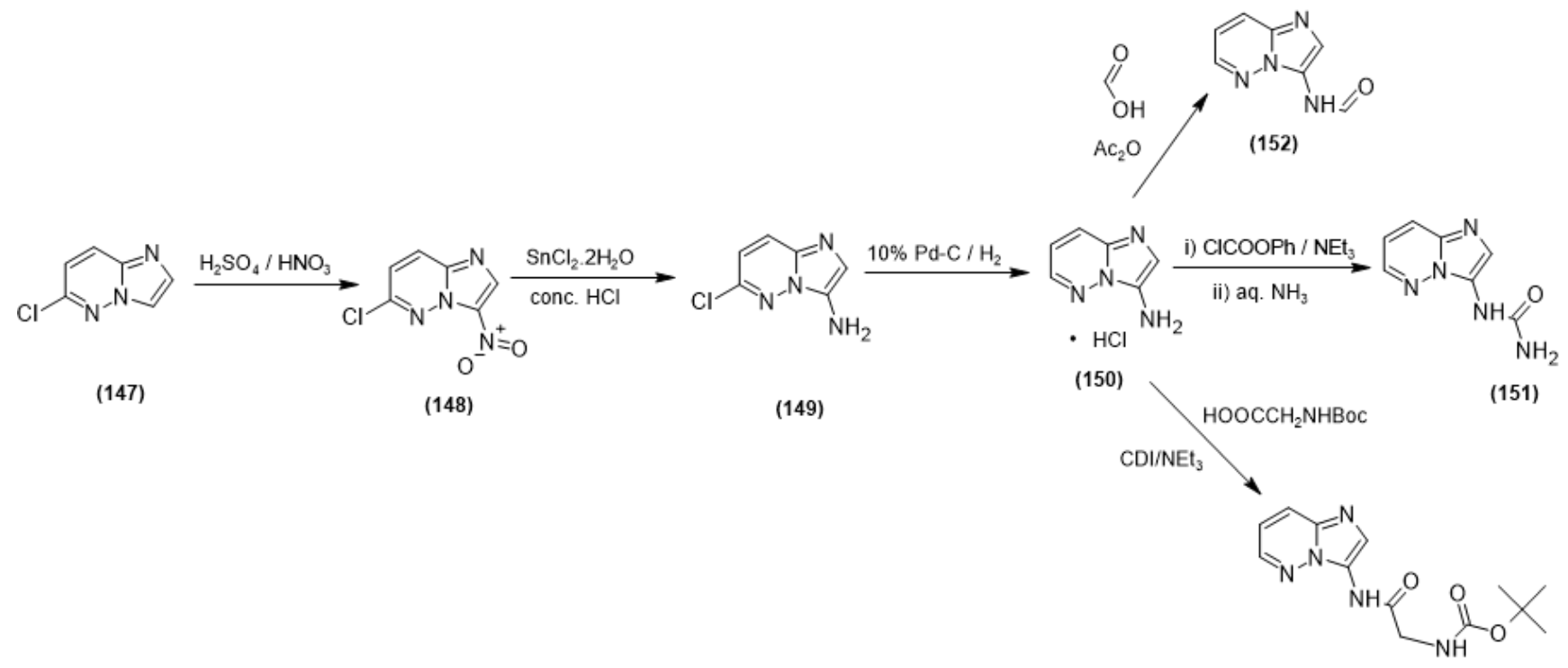

(153)

Scheme 20: Starting from 6-chloro-IMP, 3-amino-IMP was obtained and many other substances were prepared from the latter.<smiles>COc1ccc2nccn2n1</smiles><smiles></smiles>
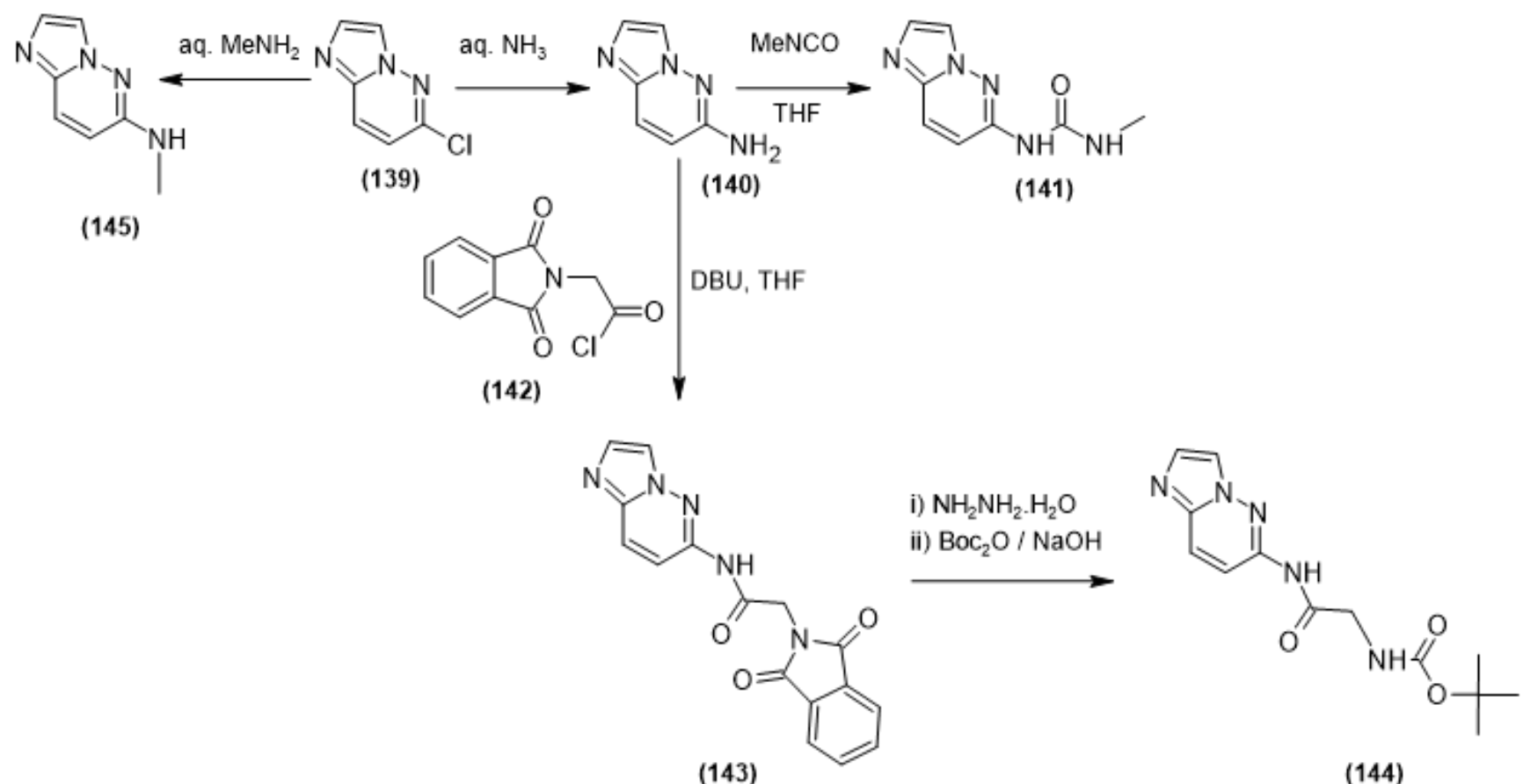

Scheme 21: Several reactions of the IMP skeleton with amines and phthalimides.

(144) 
Akkurt B. JOTCSA. 2021; 8(4): 1217-1250.

REVIEW ARTICLE<smiles>NC(=O)c1ccc(N)nn1</smiles>

(154)<smiles>NC(=O)c1ccc2nccn2n1</smiles>

(156) i) $\mathrm{ClCOO}-i-\mathrm{Bu}, i-\mathrm{Pr}_{2} \mathrm{NEt} / \mathrm{DMF}$

ii) aq. $\mathrm{CH}_{3} \mathrm{NH}_{2}$

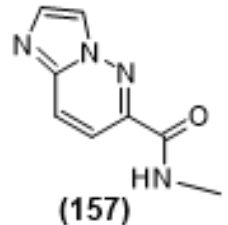

(155) $\mathrm{H}_{2} \mathrm{NCH}_{2} \mathrm{CH}_{2} \mathrm{NHBoC}$
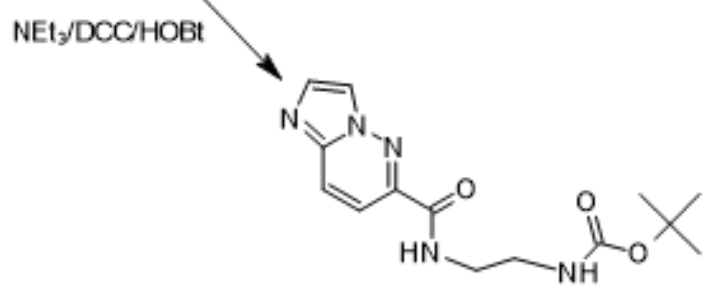

(158)

Scheme 22: Formation of IMP heterocyclic system and synthesis of two different compounds ( $\mathbf{1 5 7}$ and 158) from the carboxy-terminated IMP molecule.<smiles>[R]c1ccc(Oc2ccc3nc(NC(=O)C4CC4)cn3n2)cc1NC(=O)c1cc(C)nn1C</smiles>

(159)<smiles></smiles>

(160)

Figure 25: Design of a new compound (160) which has dual c-Met and VEGFR2 inhibition properties.

\section{Arene C-H Functionalization}

One equivalent of arene and two equivalents of substituted pyrazole were reacted to obtain the pyrazole-substituted IMP compound in $49 \%$ yield, in which a $\mathrm{C}-\mathrm{H}$ functionalization was effected with a combination of photochemistry and electrochemistry (see Scheme 23) (52). 
<smiles></smiles>

(1)<smiles>c1cn[nH]c1</smiles>

(161) photoelectrochemistry<smiles>CC1(C)CCCC(C)(C)N1[O]</smiles>

TEMPO<smiles></smiles>

(162)<smiles>Cc1cc(C)c(-c2c3ccccc3[n+](C)c3ccccc23)c(C)c1</smiles>

[Mes-Acr']

(164)<smiles>CC[N+](CC)(CC)CC</smiles>

(163)

$\mathrm{NEt}_{4} \mathrm{PF}_{6}$

(165)

Scheme 23: Using photoelectrochemical conditions led to a C-H functionalization of IMP and pyrrole. Reaction conditions: Arene, 1 equivalent, pyrrole, 2 equivalent; [Mes-Acr ${ }^{+}$, 5 mol\%, TEMPO, (20 mol\%), Et $4 \mathrm{NBF}_{4}$ (0,1 equivalent), dichloroethane, blue LED, 2 mA, 16 h.

In another study, new and functionalized heteroarenes were prepared via dehydrogenative cross-coupling. One of the studied compounds<smiles>c1cnn2ccnc2c1</smiles>

(166)<smiles>C1CCCCC1</smiles>

(167)

contained IMP skeleton and it was successfully alkylated (see Scheme 24) (53).
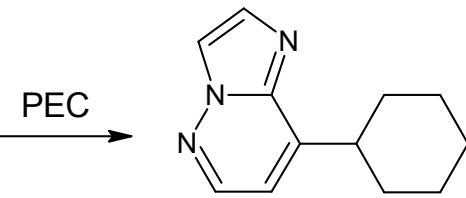

(168)

Scheme 24: Photoelectrochemistry of the IMP-cyclohexane system yields the 8-cyclohexyl-IMP molecule. Reaction conditions: 0.3 equivalent $\mathrm{Et}_{4} \mathrm{NCl}, 6$ equivalents of $\mathrm{HCl}$, acetonitrile, $392 \mathrm{~nm}, 10 \mathrm{~W}$ LED, $2 \mathrm{~mA}$. RVC anode, Pt cathode, $0.3 \mathrm{mmol}$ heteroarene, $1 \mathrm{~mL}$ of cyclohexane, $6 \mathrm{~mL}$ of acetonitrile, $34-42{ }^{\circ} \mathrm{C}$ internal temperature.

Huang and co-workers reported another instance of $\mathrm{C}-\mathrm{H}$ activation, in which (trifluoromethoxy)IMP derivative was successfully synthesized from a bromobenzene derivative, the heterocycle, and a catalytic amount of palladium acetate. The trifluoromethoxy substituent was changed to $\mathrm{m}$ trifluoromethoxyphenyl, and it was successful, too. The research group tried another starting compound having difluoromethoxyphenyl group, and the IMP- containing new heterocycle was also obtained nicely. 5-bromo-2,2-difluorobenzo[d][1,3]dioxole led to a substituted IMP in $86 \%$ yield. Lastly, they reacted 1-bromo-4- $(1,1,2,2-$ tetrafluoroethoxy)benzene with IMP and obtained, with $87 \%$ yield, the substituted compound (see Scheme 25, Scheme 26, Scheme 27, Scheme 28) (54). 
<smiles>FC(F)(F)Oc1cccc(Br)c1</smiles>

(169)<smiles>FC(F)(F)Oc1cccc(-c2cnc3cccnn23)c1</smiles>

(171)<smiles>[3H]c1cnc2cccnn12</smiles>

(1)<smiles>FC(F)(F)Oc1ccc(Cl)c(-c2cnc3cccnn23)c1</smiles>

(172)<smiles>FC(F)(F)Oc1ccc(-c2cnc3cccnn23)cc1</smiles>

Scheme 25: Three $\mathrm{C}-\mathrm{H}$ functionalization examples for IMP; reaction conditions, IMP, 1.5 equivalents; $\mathrm{Pd}(\mathrm{OAc}) 2,1 \mathrm{~mol} \%$; KOAC, 2 equivalents; $\mathrm{DMA}, 150^{\circ} \mathrm{C}, 16$ hours.<smiles>FC(F)Oc1ccccc1Br</smiles>

(174)<smiles>c1cnn2ccnc2c1</smiles>

(1)

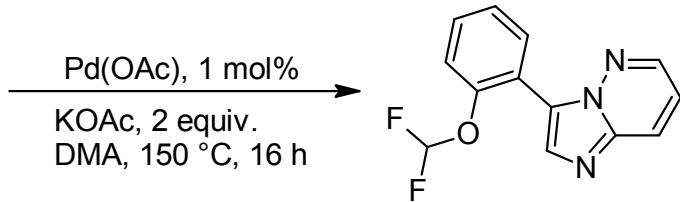

(175)

Scheme 26: 3-(2-difluoromethyl)phenyl-containing IMP molecule, IMP was used in 1.5 equivalents to the bromo compound.<smiles>FC1(F)Oc2ccc(Br)cc2O1</smiles>

(176)

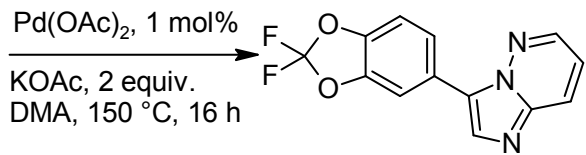

(177)

Scheme 27: Another $\mathrm{C}-\mathrm{H}$ functionalization example for IMP.<smiles>FC(F)C(F)(F)Oc1ccc(Br)cc1</smiles>

(178)<smiles>c1cnn2ccnc2c1</smiles>

(1)
$\mathrm{Pd}(\mathrm{OAc})_{2}, 1 \mathrm{~mol} \%$

KOAc, 2 equiv. DMA, $150^{\circ} \mathrm{C}, 16 \mathrm{~h}$<smiles>FC(F)C(F)(F)Oc1ccc(-c2cnc3cccnn23)cc1</smiles>

(179)

Scheme 28: The preparation scheme for tetrafluoroethoxyphenyl-containing IMP molecule. IMP was taken 1.5 equivalents with respect to the bromo compound.

Mao et al. published another of their publications about $\mathrm{C}-\mathrm{H}$ activation of IMP with $\mathrm{Pd} / \mathrm{C}$ in green solvents (see Scheme 29) (55). Bouzayani and coworkers investigated the reactivity of positions $\mathrm{C} 9$ and $\mathrm{C} 10$ of 9 - or 10-bromophenanthrenes and for catalyst, they used $0.5-0.1 \mathrm{~mol} \%$ of phosphine-free $\mathrm{Pd}(\mathrm{OAc})_{2}$. They also successfully reacted imidazopyridazines introduced at phenanthrene C9position (see Scheme 30) (56).<smiles>c1cnn2ccnc2c1</smiles>

(1)<smiles>[R]c1ccc(Br)cc1</smiles>

(188)

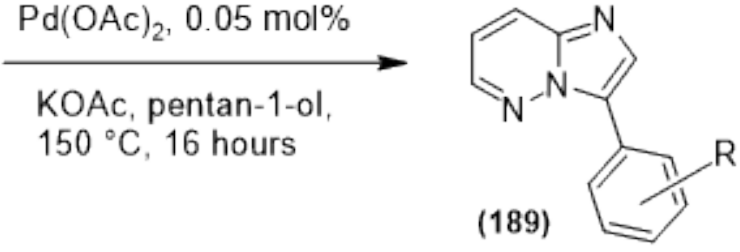


<smiles>c1cnn2ccnc2c1</smiles>

(1)<smiles>[R][X]1ccc(Br)cc1</smiles>

(190)

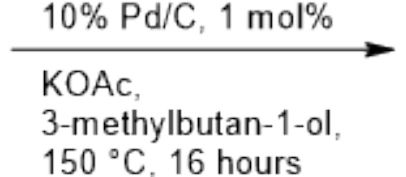

$150^{\circ} \mathrm{C}, 16$ hours<smiles>[R]c1cccc(-c2cnc3cccnn23)c1</smiles>

(191)

Scheme 29: Addition of a bromobenzene derivative or pyridine to IMP to yield 3-substituted IMP; R groups are 4-cyano, 4-nitro, 4-chloro, 4-methoxy, and 2-cyano.<smiles>Brc1cc2ccccc2c2ccccc12</smiles>

(186)<smiles>Fc1ccc2nccn2n1</smiles>

(1)

\section{$\mathrm{Pd}(\mathrm{OAc})_{2}, 0.5 \mathrm{~mol} \%$ \\ DMA, KOAC, \\ $150{ }^{\circ} \mathrm{C}, 16$ hours}

Scheme 30: 1.3 equivalents of IMP was used to obtain the phenanthrene-substituted molecule in good yield.

In another publication, green solvents associated to $\mathrm{Pd} / \mathrm{C}$ were investigated in the $\mathrm{C}-\mathrm{H}$ arylation in which metal residues cause contamination in the environment. The research team found that only 1 $\mathrm{mol} \%$ of $\mathrm{Pd} / \mathrm{C}$ allows, very efficiently, for the the direct arylations of most heteroaromatic compounds. With this catalyst and potassium acetate as the base, the direct arylation of many compounds, including IMP derivatives, were effected, using aryl bromides as coupling partners, in a high regioselectively and in moderate to very high yields. Electron-deficient and electron-rich aryl bromides were tolerated; what is more, for the most reactive heteroarenes, $\mathrm{Pd} / \mathrm{C}$ catalyst tolerated green solvents such as diethyl carbonate, 3-methylbutan1-ol and pentan-1-ol, provided a low impact to the environment (see Scheme 31, Scheme 32, Scheme 33) (57).<smiles>c1cnn2ccnc2c1</smiles>

(1)<smiles>[X]c1ccc([R])cc1</smiles>

(180)

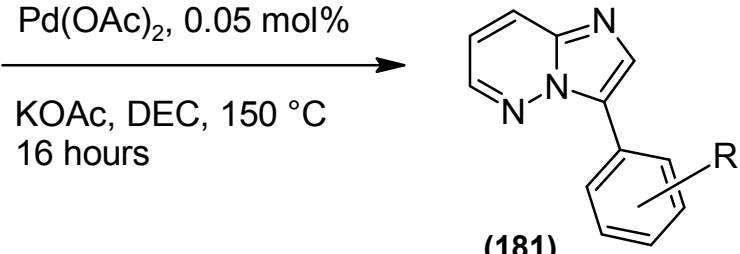

(181)

Scheme 31: IMP is coupled to haloarenes in diethylcarbonate with $P d(O A c) . X=B r, R=4-O M e ; X=B r, R=$ $4-\mathrm{NO}_{2} ; \mathrm{X}=\mathrm{Br}, \mathrm{R}=4-\mathrm{COMe} ; \mathrm{X}=\mathrm{Cl}, \mathrm{R}=4-\mathrm{CN}(*) ; \mathrm{X}=\mathrm{Cl}, \mathrm{R}=4-\mathrm{CF}_{3}(*) ; \mathrm{X}=\mathrm{Cl}, \mathrm{R}=4-\mathrm{CO}_{2} \mathrm{Me}(*) ; \mathrm{X}=\mathrm{Cl}, \mathrm{R}$ $=3-\mathrm{CN}(*)$. For $\mathrm{X}$ and $\mathrm{R}$ pairs, asterisk indicates that $\mathrm{Pd}(\mathrm{OAC})_{2}$ was taken in $0.1 \mathrm{~mol} \%$.<smiles>c1cnn2ccnc2c1</smiles>

(1)

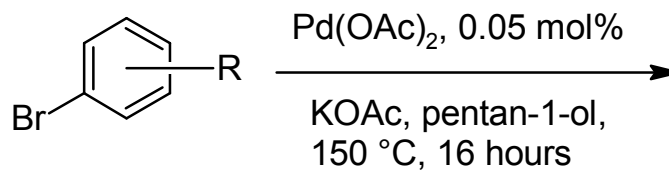

(182)<smiles>[R]c1cccc(-c2cnc3cccnn23)c1</smiles>

(183)

Scheme 32: Several examples concerning the $\mathrm{C}$-H activation of IMP, having 3-substituted phenyl group. $\mathrm{R}$ is 4-cyano, 4-nitro, 4-formyl, 4-acetyl, 4-fluoro, 4-methoxy, 3-carboxymethyl, and 2-cyano. 
<smiles>c1cnn2ccnc2c1</smiles>

(1)<smiles>[R]c1ccc(Br)cc1</smiles>

(184)

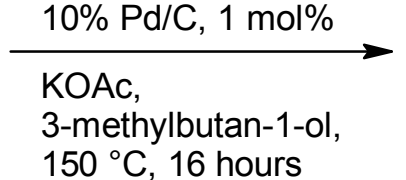

$150{ }^{\circ} \mathrm{C}, 16$ hours<smiles>[R]c1cccc(-c2cnc3cccnn23)c1</smiles>

(185)

Scheme 33: Instead of palladium(II) acetate, $10 \% \mathrm{Pd} / \mathrm{C}$ was used in $1 \mathrm{~mol} \%$ proportion. $\mathrm{R}$ is 4 -cyano (in DEC, a reduced yield was observed), 4-nitro (in DEC, a reduced yield was observed), 4-chloro, 4-methoxy, and 2-cyano.

According to computational predictions, many bridging-nitrogen polyaromatic compounds, such as IMP derivatives, should be susceptible to oxidation by the photocatalyst. This hypothesis was verified in experimental manner, and in most cases, only a single regioisomer was obtained. Whatever the substituents are, derivatives of IMP yielded 3substituted functionalization products. When two halogen substituents are present in the IMP derivative, and although it is more electrondeficient, this IMP derivative was obtained with a dramatic loss of reaction yield and it is important to stress that substitution still occurred at the 3position. For IMP derivatives and imidazo[1,2a]pyrimidines, there is an enamine character in the ring. Similarly to $\mathrm{N}$-methylpyrazoles, these nitrogenbridged heterocycles react at the electrophilic carbon of the iminium radical (see Scheme 34) (19).

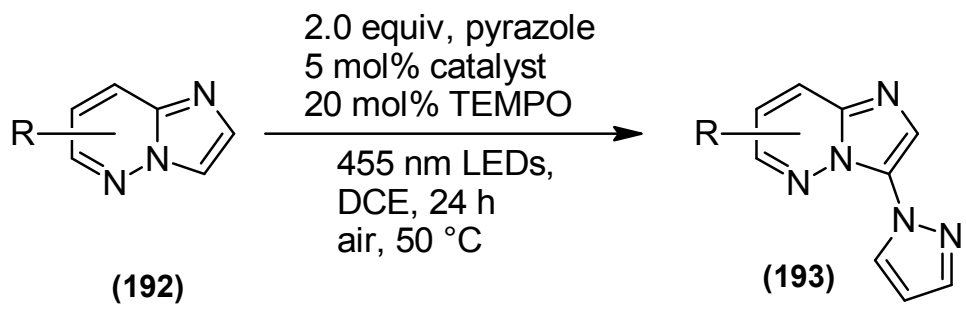

Scheme 34: Addition of pyrazole nucleus to IMP at position 3. When no substituent is present, the reaction yield is $70 \%$. When a $\mathrm{Cl}$ is bound to position 6 , the yield is $50 \%$. Finally, when 2 -phenyl- and 6 -chloro- are present, the yield is $73 \%$.

Chikhi and co-workers reported on the Pd-catalyzed direct arylation of IMP. Phosphine-free $\mathrm{Pd}(\mathrm{OAC})_{2}$ was found to be a very efficient catalyst in the the direct arylation of IMP at C3 position, with employing a very low catalyst loading. The reaction requires only 0.1-0.05 mol\% catalyst loading, works with a wide range of aryl bromides, and yields very high TOF and TON numbers. Some electron-deficient aryl chlorides were also observed to work well as substrates. Green, safe, and renewable solvents like pentan-1-ol were used in the synthesis of 31 examples, and the efficiency did not go down (see Scheme 35, Scheme 36, Scheme 37, Scheme 38, Scheme 39) (58).<smiles>c1cnn2ccnc2c1</smiles>

(1)<smiles>N#Cc1ccc(Br)cc1</smiles>

(194)

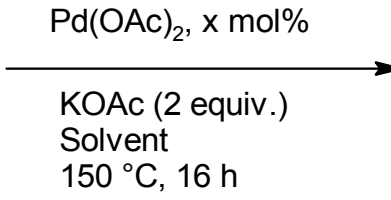

$(195$<smiles>N#Cc1ccc(-c2cnc3cccnn23)cc1</smiles>

Scheme 35: Optimization of the catalyst in preparing 3-(4-cyanophenyl)IMP. The solvents with highest yields based on the product were DMA, pentan-1-ol, and CPME. Catalyst percentage was 0.05 mol\% in the mentioned green solvents and in the subsequent experiments, this percentage was used. 


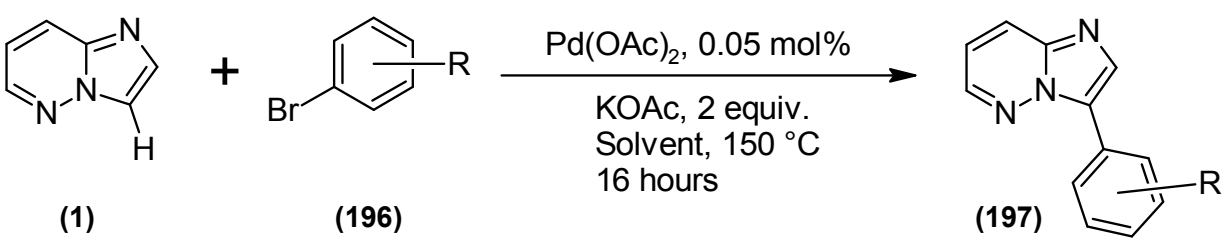

Scheme 36: C-H functionalization of IMP with several bromobenzenes. $\mathrm{R}$ is 4-OMe, 4- $\mathrm{NO}_{2}, 4-\mathrm{CHO}, 4-\mathrm{COMe}$, 4-COOEt, 4-Cl, 4-F, 4-Me, 4- $\mathrm{NH}_{2}$, 3-COOMe, 3-COMe, 3-Br, 3- $\mathrm{NH}_{2}, 3,5-\mathrm{bis}\left(\mathrm{CF}_{3}\right)$, 2-CN, 2-CHO, 2-CF 3 , 1naphthyl (instead of benzene), 1-pyrenyl (instead of benzene), 3-quinolinyl (instead of benzene), 3-pyridyl (instead of benzene), and 5-pyrimidinyl (instead of benzene). Some reactions were conducted in diethylcarbonate, pentan-1-ol, or CPME instead of DMA.<smiles>[3H]c1cc2ncccc2nn1</smiles>

(1)<smiles>[R]c1ccc(Cl)cc1</smiles>

(198)

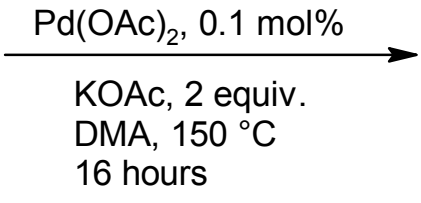

16 hours<smiles>[R]c1ccc(-c2cnc3cccnn23)cc1</smiles>

Scheme 37: Using chlorobenzene derivatives instead of bromobenzenes: Reaction conditions and products. IMP was taken in 1.1 equivalents. $\mathrm{R}$ is $4-\mathrm{CN}, 4-\mathrm{NO}_{2}, 4-\mathrm{CF}_{3}, 4-\mathrm{COOMe}, 3-\mathrm{CN}, 3-\mathrm{NO}_{2}, 2-\mathrm{NO}_{2}$, and 4-NO2-2CN.<smiles>Clc1ccc2nccn2n1</smiles>

(200)<smiles>[R]c1ccc(Br)cc1</smiles>

(201)

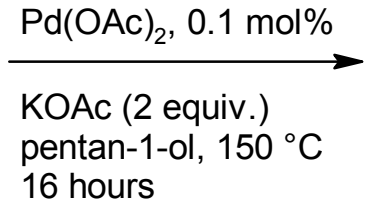
16 hours<smiles>[R]c1cccc(-c2cnc3ccc(Cl)nn23)c1</smiles>

Scheme 38: 6-Chloro-IMP was treated with bromobenzene derivatives to afford a series of 3-(substituted phenyl) IMP compounds. $\mathrm{R}$ is 4- $\mathrm{NO}_{2}, 4-\mathrm{CHO}, 4-\mathrm{Br}, 2-\mathrm{COOMe}$, 1-naphthyl, 3-quinolinyl, and 3-pyridyl.<smiles>Fc1ccc(-c2cnc3cccnn23)cc1</smiles>

(203)

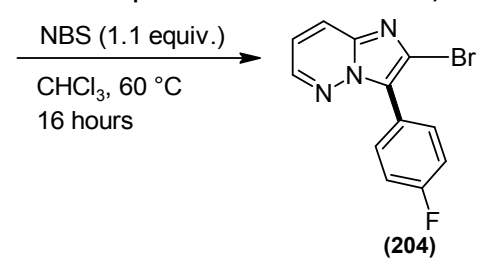

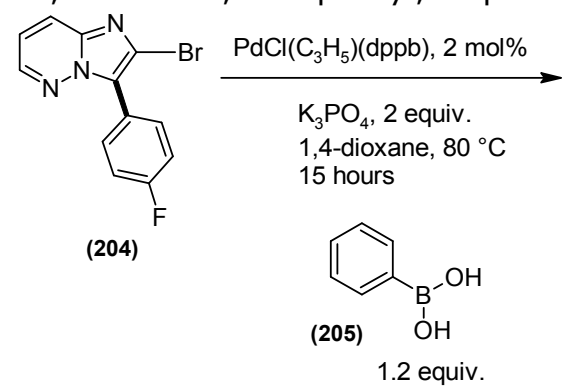

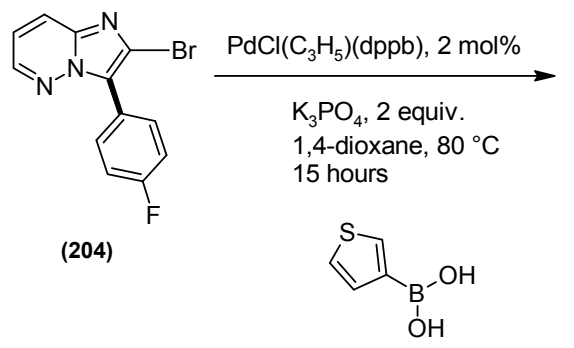

1.2 equiv.

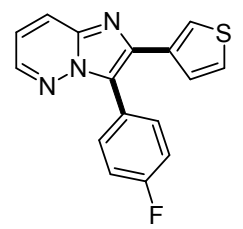

(208)<smiles>Fc1ccc(-c2cnc3cccnn23)cc1</smiles>

(203)

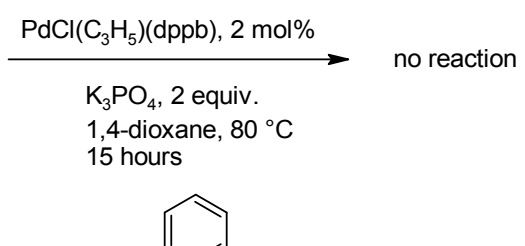

(207)

Scheme 39: Bromination of 3-(4-fluorophenyl)substituted IMP and further substitutions at 2 position.

A wide spectrum of biological and therapeutic properties is known for imidazo[1,2-b]pyridazine derivatives, but there is only one method in the literature for the synthesis of a 3-arylimidazo-IMP derivative via palladium-catalyzed regioselective arylation of IMP. Treatment of IMP with 4- 
bromotoluene in 1,4-dioxane at $100{ }^{\circ} \mathrm{C}$, where $\mathrm{Cs}_{2} \mathrm{CO}_{3}$ was used as a base along with a catalytic amount of $\mathrm{Pd}\left(\mathrm{PPh}_{3}\right)_{4}$ gives 3-(4-tolyl)IMP in $92 \%$ yield (see Scheme 40) (59).<smiles>c1cnn2ccnc2c1</smiles>

(1)<smiles>Cc1ccc(Br)cc1</smiles>

1.3 equiv.

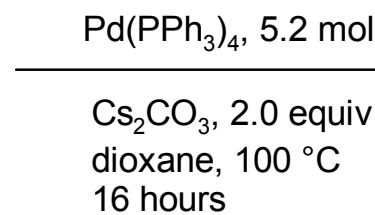

16 hours

(210)<smiles>Cc1ccc(-c2cnc3cccnn23)cc1</smiles>

(211)

Scheme 40: Another $\mathrm{C}-\mathrm{H}$ functionalization with phosphine-containing palladium complex.

Addition of Alkynes or Osmium Carbynes to Functionalized d-n Conjugated Systems

Chen and co-workers reported a reaction of metal carbynes and alkynes yielding acyclic addition products. These reactions are newly discovered and are highly efficient, regio- and stereospecific, along with a nice tolerance of functional groups, and even are stable under air and at room temperature. The authors reported that the synthesized materials could find use in functional materials (see Scheme 41) (20).

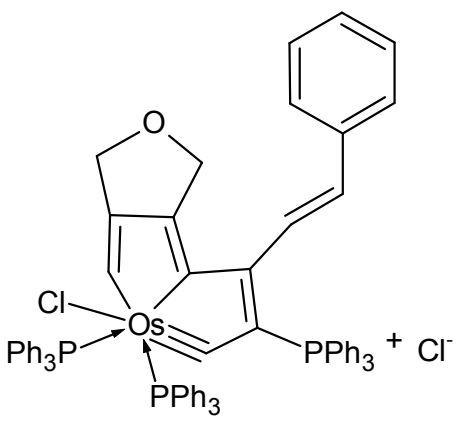

(212)

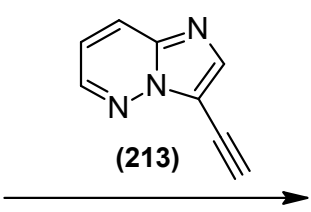

$\mathrm{HCl} . \mathrm{Et}_{2} \mathrm{O}, \mathrm{RT}$

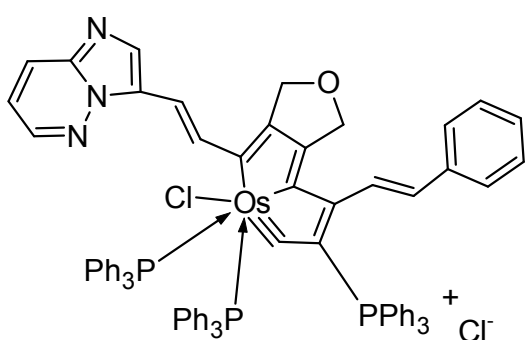

(214)

Scheme 41: Osmium carbyne reacting with an alkyne-containing IMP derivative.

\section{Site-Selective C-H Silylation of Azines}

For the site-selective $\mathrm{sp}^{2} \mathrm{C}-\mathrm{H}$ silylation of azines, Gu et al. have devised a base-mediated synthetic method. Authors report that the conditions are mild, the protocol is simple, and for a diverse set of azines, the site selectivity is excellent. With classical silylations, orthogonal reactivity was discussed (60).
Another group has reported about visible lightpromoted photocatalytic $\mathrm{C}-\mathrm{H}$ silylation. This method enables the direct coupling of trialkylhydrosilanes with electron-deficient and electron-rich heteroarenes and also with cyano-bearing arenes. The yields are moderate to high and regioselectivity is good (see Scheme 42, Scheme 43) (21).<smiles>c1cnn2ccnc2c1</smiles>

(1)<smiles>CC[Si](CC)(CC)B1OC(C)(C)C(C)(C)O1</smiles>

(215)<smiles>[Z2][NH+]([Si](C)(C)C)[Si](C)(C)C</smiles>

(216)<smiles>CC[Si](CC)(CC)c1ccnn2ccnc12</smiles>

(217)

Scheme 42: Silylation of IMP. 
<smiles>CC(C)(C)[Si](C)(C)[Te]c1cn2ncccc2n1</smiles>

(1)
23 W CFL, photocatalyst (1 mol\%)

$\mathrm{Na}_{2} \mathrm{~S}_{2} \mathrm{O}_{8}$ (2 equiv.), open flask

DMSO/DCE (1:1), $30{ }^{\circ} \mathrm{C}, 24 \mathrm{~h}$

$\left[\operatorname{lr}(\text { ppy })_{2}(\right.$ dtbbpy $) \mathrm{PF}_{6}$ was used<smiles>CC(C)(C)[Si](C)(C)c1ccnn2ccnc12</smiles>

(220)

Scheme 43: C-Si bond formation of IMP and dimethyl-tert-butylsilane and C8 product is twice as much as the $\mathrm{C7}$ product.

Photoelectrochemical C-H Alkylation of obtaining and using alkyl radicals. Using primary, Heteroarenes with Organotrifluoroborates secondary and tertiary alkyltrifluoroborates, a Electrocatalysis and photoredox catalysis are joined to provide an approach which does not use chemical oxidants and organotrifluoroborates were used for variety of heteroarenes were functionalized and the regioselectivity and chemoselectivity were found to be excellent (see Scheme 44) (22).

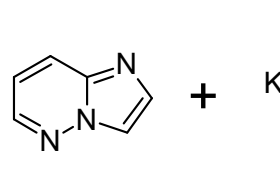

(1)<smiles>F[B-](F)(F)C1CCCCC1</smiles>

(221)<smiles>Cc1cc(C)c(-c2c3ccccc3[n+](C)c3ccccc23)c(C)c1</smiles><smiles>c1cn2ccn3nccc3c2n1</smiles>

(223)

Scheme 44: Photoelectrochemistry of IMP with cyclohexyltrifluoroborate potassium salt to give 8cyclohexyl-IMP.

\section{Photoinduced Oxidative Activation of Electron-} Rich Arenes

$\mathrm{Hu}$ and coworkers published a photo-induced the dehydrogenative cross-coupling between electronrich arenes and styrene derivatives using a dual catalytic system, in which an acridinium photosensitizer and a cobaloxime proton-reducing catalyst were used. $\mathrm{H}_{2}$ evolution was evidenced with this catalytic system, using the $\mathrm{Csp}^{2}-\mathrm{Csp}^{2}$ bond formation. Various substituted aryl alkenes can be afforded with good to excellent yields and high $\beta$ regioselectivity (see Scheme 45) (23).<smiles>C=C(c1ccccc1)c1ccccc1</smiles>

(1)

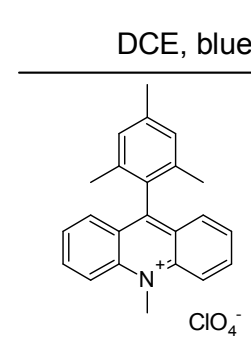

$3 \mathrm{~mol} \%$

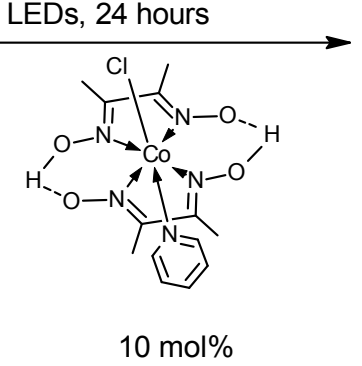

(225)

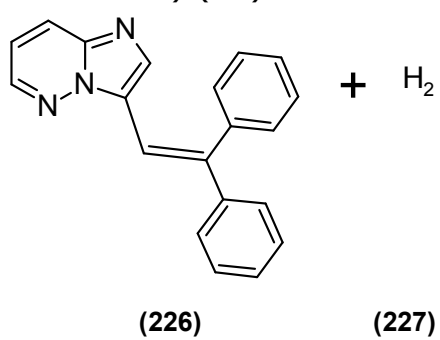

(227)

(222)

Scheme 45: Functionalization of IMP with diphenylethenyl moiety.

Use of Sonogashira Coupling for an Easier Intermediate to Ponatinib

Handa and coworkers devised an easier path in which an iron-palladium nanoparticle was used to the intermediate of Ponatinib (see Scheme 46), also referred to as "intermediate 37 " (61). 


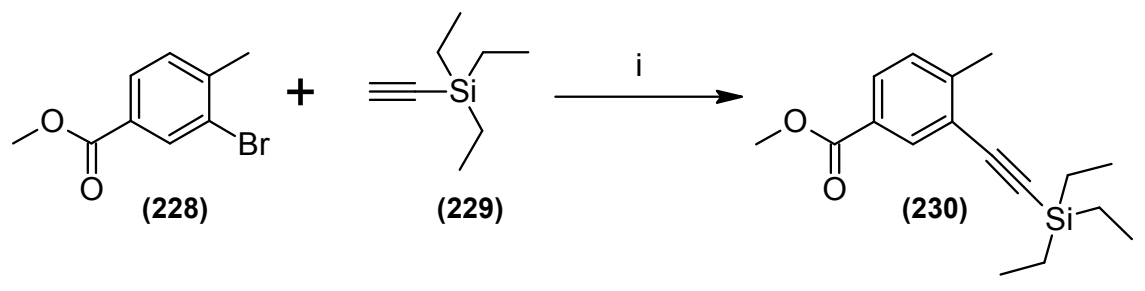

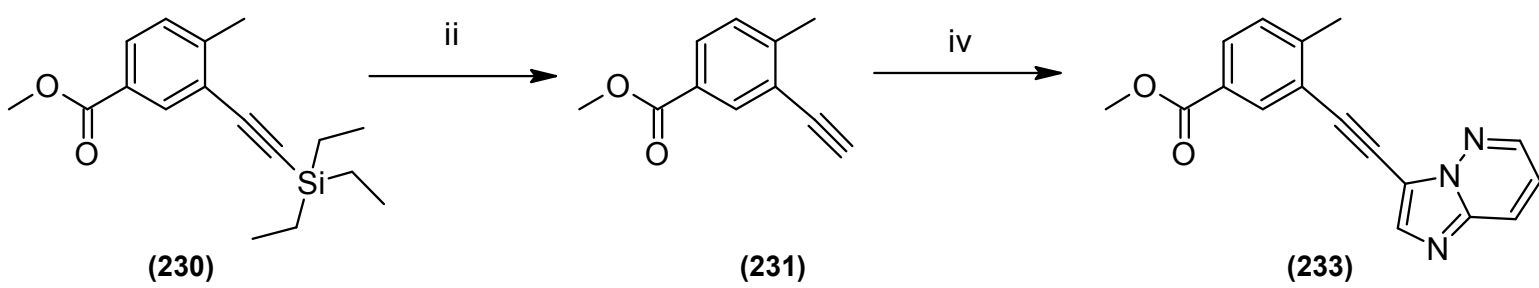<smiles>CC#CCCC</smiles>

(1)

(232)

Scheme 46: An easier path to Ponatinib intermediate 37. Reaction conditions: i) 3-bromo-4-methylbenzoic acid methyl ester, 1.0 equiv.; (triethylsilyl)acetylene, 1.5 equiv.; Fe/ppm Pd NPs (contains 500 ppm Pd); $\mathrm{Et}_{3} \mathrm{~N}$, 3.0 equiv.; $0.5 \mathrm{M}$ in 2 wt\% TPGS-750 M/ $\mathrm{H}_{2} \mathrm{O}, 50{ }^{\circ} \mathrm{C}$, argon, 14 hours. ii) 3-(triethylsilylacetylene)-4methylbenzoic acid methyl ester, 1.0 equiv.; $\mathrm{K}_{2} \mathrm{CO}_{3}, 20 \mathrm{~mol} \%, 0.5 \mathrm{M}$ in $1: 1 \mathrm{MeOH} / \mathrm{THF}, 45{ }^{\circ} \mathrm{C}, 5$ hours. iii) IMP, 1.0 equiv., $N$-iodosuccinimide, 1.2 equiv., $0.53 \mathrm{M}$ in DMF; $80{ }^{\circ} \mathrm{C}$, argon, overnight. iv) 3-iodo-IMP, 1.0 equiv.; 3-(triethylsilylacetylene)-4-methylbenzoic acid methyl ester, 1.2 equiv.; Fe/ppm Pd NPs (contains 1000 ppm Pd), Et ${ }_{3} \mathrm{~N}$, 3.0 equiv.; $0.5 \mathrm{M}$ in 2 wt\% TPGS-750-M/ $\mathrm{H}_{2} \mathrm{O}, 50{ }^{\circ} \mathrm{C}$, argon, 43 hours.

Oxidation with CAN of Aryl and Heteroaryl Hydazines and Hydrazides

Aryl and heteroaryl hydrazines and hydrazides were oxidized with ceric ammonium nitrate (CAN) and dehydrazinated products were observed. The reaction was dependent upon the substrate and hydrocarbons and alkoxy compounds were obtained (24).

\section{IMP Derivatives as Brominating Agents}

Dr. Branko Stanovnik is and has been a pioneer in the IMP chemistry. He and his colleagues devised three brominating agents from 3-bromo-6-chloro-2methyl-IMP-bromine, 3-bromo-IMP-bromine, and 3bromo-6-chloro-IMP-bromine. These were prepared by starting from IMP or 6-chloro-IMP by applying bromine in acetic acid. Using 3-bromo-6-chloro-2methyl-IMP-bromine, they described a method about how to brominate a-ergocryptine and similar ergot alkaloids, to obtain the corresponding 2bromo derivatives in pure form, with reaction yields up to $81 \%$. When comparing this brominating agent with the others already known in the literature, this new brominating agent was found to be advantageous. Alkenes, ketones, 3-oxoalkanoic acid esters, monocylic $\mathrm{N}$-heterocycles, and polycyclic Nheterocycles were successfully brominated with 3bromo-IMP-bromine and 3-bromo-6-chloro-IMPbromine. 1,2-Trans-dibromocyclohexane was synthesized from cyclohexene. Alkynyl ketones and 3-oxoalkanoic acid esters were obtained as a-bromo derivatives. At position 5, 2-aminopyridine and 2aminopyrimidine were successfully brominated. It is however different when these two compounds were reacted with the IMP derivative, bromination occurred at position 3. At room temperature, or on gentle heating, the brominations with these reagents were completed smoothly (see Scheme 47, Scheme 48) $(25,62)$.<smiles>Cc1nc2ccc(Cl)nn2c1Br</smiles><smiles>Cc1nc2ccc(Cl)nn2c1[18OH]</smiles>

Scheme 47: Stanovnik and his colleagues performed this bromination and obtained a powerful brominating agent. 6-Cl may be 6- $\mathrm{H}$, and $2-\mathrm{CH}_{3}$ may be $2-\mathrm{H}$. 


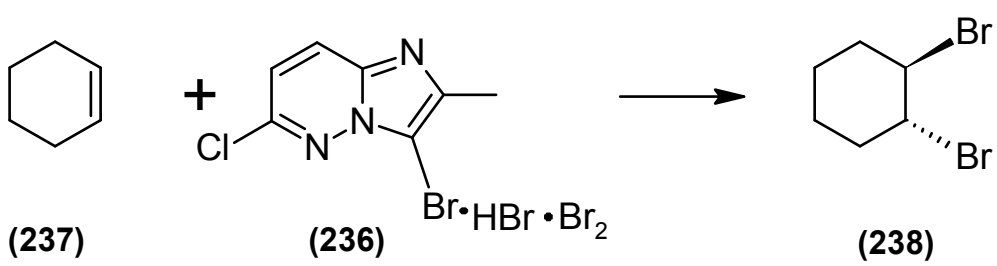

Scheme 48: Application of the IMP-brominating agent with cyclohexene to obtain the 1,2-dibromo compound.

\section{IMP-CONTAINING MOLECULES IN MATERIAL SCIENCE}

Red Phosphorescent Organic Light-Emitting Devices

IMP was, for the first time, considered as a host material in OLEDs. The heterocycle possesses an excellent ability of electron-transportation, and an extreme thermal stability. As the p-type unit, carbazole was chosen, while IMP was the n-type unit. The most promising compounds were 6substituted and 6,8-substituted in terms of the best electroluminescent performance (see Figure 26) (26).

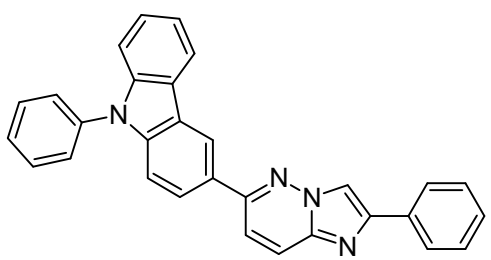

IP6Cz

(239)

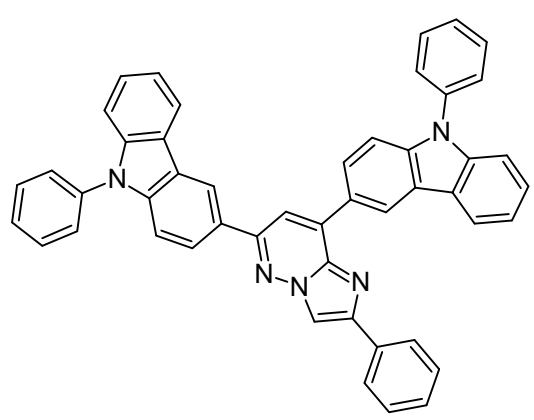

IP68Cz

(241)
Photochromic

\section{Iodoargentate Hybrid Materials}

Imidazopyridazinium

Three iodoargentate hybrids with the respective closed formulas [MIPDz $]_{2}\left[\mathrm{Ag}_{2} \mathrm{I}_{4}\right]$, [AIPDz][ $\left.\mathrm{Ag}_{2} \mathrm{I}_{3}\right]$, and $[\mathrm{MIPDz}]_{2}\left[\mathrm{Ag}_{5} \mathrm{II}_{7}\right]$, in which $\mathrm{MIPDz}^{+}$is methylimidazopyridazinium, and $\mathrm{AIPDz}^{+}$is acetonylimidazopyridazinium. They showed good photochromism and hierarchically responsive mechanism where they were optically inert and then they underwent photolysis of iodoargentates, and as secondary electron donor, Ag particles play a role in the photoinduced intermolecular electron transfer (see Scheme 49) (27).

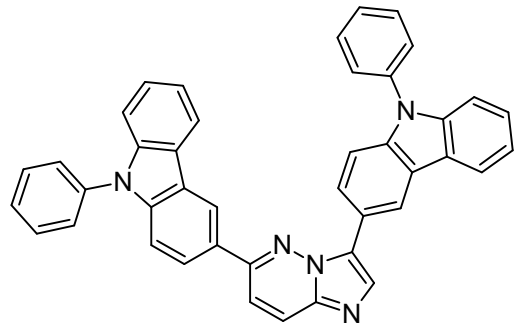

$\mathrm{IP} 36 \mathrm{Cz}$

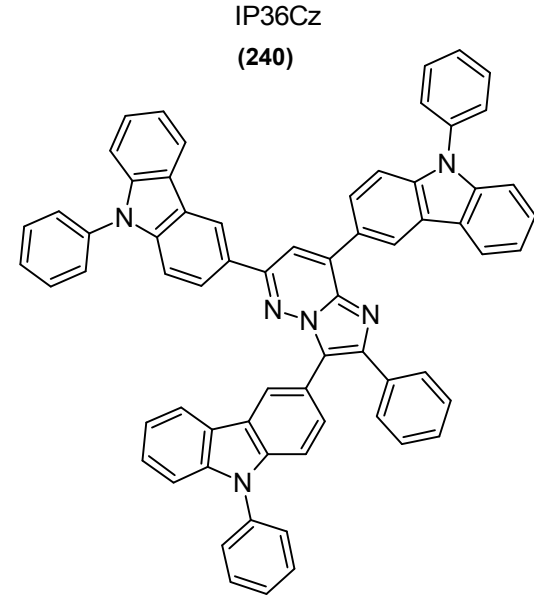

IP368Cz

(242)

Figure 26: Carbazole-containing IMP skeletons. 3, 6, and 8 refer to the positions on the IMP skeleton on which carbazole units are bound. 


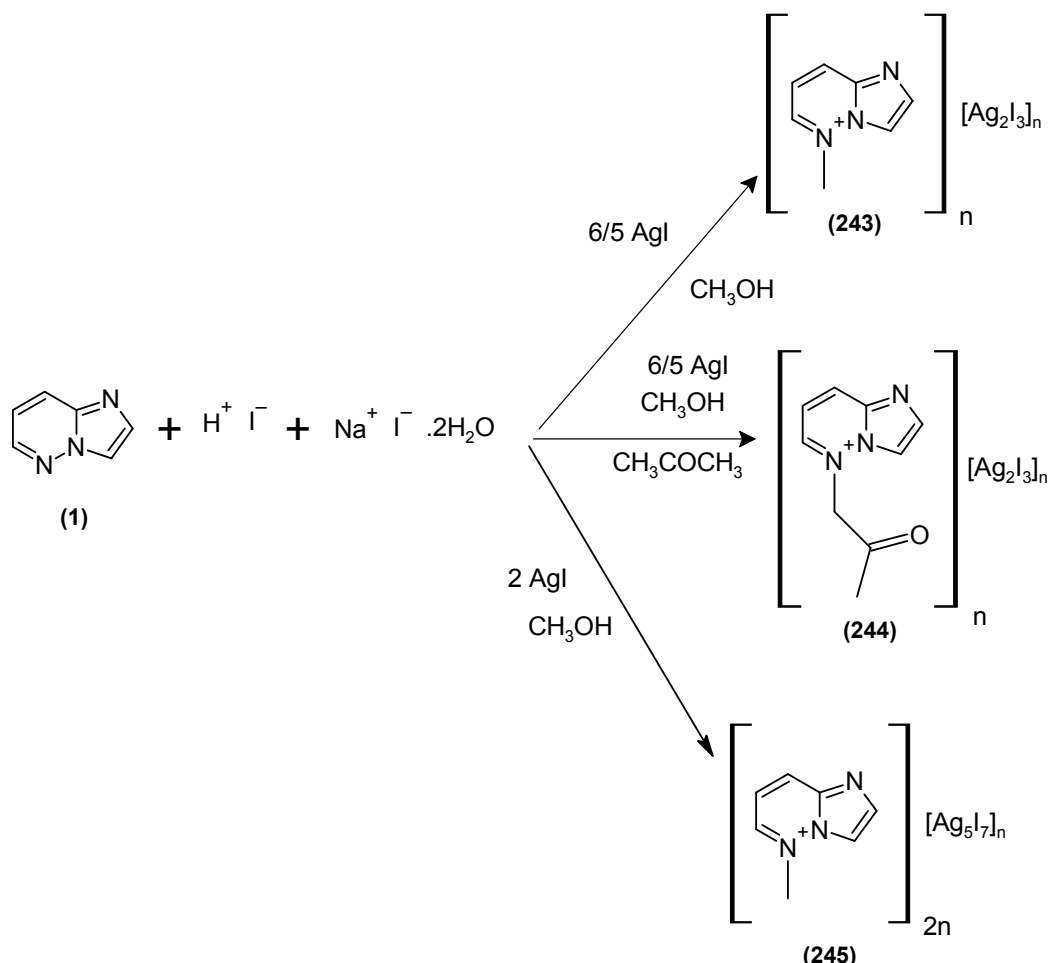

Scheme 49: Under solvothermal conditions, the three iodoargentate hybrid compounds were synthesized and used for tunable and improved photochromism.

\section{THEORETICAL-EXPERIMENTAL STUDIES}

Some heterocycles could be tested for their reported $\mathrm{C}-\mathrm{H}$ radical functionalization sites with the condensed Fukui function. This method is able to also predict the innate $\mathrm{C}-\mathrm{H}$ sites on multi-nitrogencontaining arenes. The calculated results were validated with experiments (28). In a work by Tagore and co-workers, the unsubstituted IMP molecule was studied, both theoretically and experimentally. Experimental spectral methods included FT-IR, FT-Raman, ${ }^{1} \mathrm{H}-\mathrm{NMR},{ }^{13} \mathrm{C}-\mathrm{NMR}$, and UV-Vis and comparisons with the theoretically obtained spectra yielded a high correlation with each other (63). Coulombic ion-pairing complex of the modeled compounds, as acetate ion accompanies them, was calculated in terms of the ionic interaction energy. According to the results, stability is one of the significant factors about the inhibitory potency of fibrinogen-receptor binding (64). Twenty-two azoloazine compounds were selected for carbon-13 nuclear magnetic resonance data. A stepwise linear multiple regression with nitrogen substituents in the 5- and 6-membered ring system. Pyrrolo[1,2-a]pyridine was decided to be the reference for chemical shift correlation. The researchers found that a highly correlated set of chemical parametes are present (65). The magnetic circular dichroism (MCD) B terms of the two $L$ transitions in 14 azaindolizines in neutral and protonated forms have been measured by a collaboration between an American group and a Yugoslavian research group. Interpretation was based on the perimeter model and consideration of the effect of the $-\mathrm{CH}=>-\mathrm{N}=$ and $-\mathrm{CH}=>-$ $\mathrm{NH}^{+}=$replacements on the orbital energy double difference - $\triangle$ HOMO- $\triangle$ LUMO. The INDO/S calculations seemed to fit well to the first-order perturbation theory and these calculations along with PPP calculations were successfully used to predict the $B$ terms in the MCD spectra with a good agreement (66). ${ }^{15} \mathrm{~N}$ NMR chemical shift data for 14 azolopyridines were obtained as well as the results of INDO/S-SOS calculations of nitrogen shieldings. The ${ }^{15} \mathrm{~N}$ data and their assignments are shown to be reliable for the indolizine's nitrogen as based on relative line widths. The pyridine nitrogens are more reliably assigned from the ${ }^{15} \mathrm{~N}$ spectra when complimented with INDo/S-SOS calculations for individual molecules (67). A joint work between two Yugoslavian groups yielded the orbital correlation diagram for IMP molecule and its substituted derivatives (68).

\section{CONCLUSION}

IMP and its derivatives attract a great deal of attention owing to their biological activities. Enzyme inhibition and some biological activity (antitumoral activity, etc) could be grasped in the first look. Being recognized as a heteroarene, there are also works about IMP and its derivatives, theoretical aspects this versatile molecule. The presence of many enzyme inhibition reports may attract the 
attention of researchers and a collaboration with medicinal chemists will undoubtedly lead to new and powerful molecules to be used in many diseases, including Alzheimer's, cancer, and a lot more.

\section{CONFLICT OF INTERESTS}

The author declares that there are no conflict of interests.

\section{REFERENCES}

1. Stanovnik B, Tišler M. Synthesis of pyridazine derivatives-VIII. Tetrahedron. 1967 Jan;23(1):387-95. <DOI>.

2. Liu J, Zhang Y, Huang H, Lei X, Tang G, Cao $X$, et al. Recent advances in Bcr-Abl tyrosine kinase inhibitors for overriding T315I mutation. Chem Biol Drug Des. 2021 Mar;97(3):649-64. <DOI>.

3. AbdelHaleem A, Mansour AO, AbdelKader $M$, Arafa RK. Selective VEGFR-2 inhibitors: Synthesis of pyridine derivatives, cytotoxicity and apoptosis induction profiling. Bioorganic Chem. 2020 Oct; 103:104222. <DOI $>$.

4. Pandit SS, Kulkarni MR, Ghosh U, Pandit YB, Lad NP. Synthesis and biological evaluation of imidazo[1,2-b]pyridazines as inhibitors of TNF- a production. Mol Divers. 2018 Aug;22(3):545-60. $\leq \mathrm{DOI}$.

5. Shi Q, Tebben A, Dyckman AJ, Li H, Liu C, Lin J, et al. Purine derivatives as potent Bruton's tyrosine kinase (BTK) inhibitors for autoimmune diseases. Bioorg Med Chem Lett. 2014 May;24(9):2206-11. <DOI .

6. Abdel-Maksoud MS, El-Gamal MI, Benhalilou DR, Ashraf $S$, Mohammed SA, Oh C. Mechanistic/mammalian target of rapamycin: Recent pathological aspects and inhibitors. Med Res Rev. 2019 Mar;39(2):631-64. <DOI>.

7. Amin HS, Parikh PK, Ghate MD. Medicinal chemistry strategies for the development of phosphodiesterase 10A (PDE10A) inhibitors - An update of recent progress. Eur J Med Chem. 2021 Mar;214:113155. <DOI .

8. Sato $T$, Sekimata $K$, Sakai N, Watanabe $H$, Mishima-Tsumagari C, Taguri T, et al. Structural Basis of Activin Receptor-Like Kinase 2 (R206H) Inhibition by Bis-heteroaryl Pyrazole-Based Inhibitors for the Treatment of Fibrodysplasia Ossificans Progressiva Identified by the Integration of Ligand-Based and Structure-Based Drug Design Approaches. ACS Omega. 2020 May 26;5(20):11411-23. <DOI>.

9. Alnabulsi $S$, Al-Hurani EA. Pim kinase inhibitors in cancer: medicinal chemistry insights into their activity and selectivity. Drug Discov Today. 2020 Nov;25(11):2062-9. <DOI>.

10. Farag AK, Roh EJ. Death-associated protein kinase (DAPK) family modulators: Current and future therapeutic outcomes. Med Res Rev. 2019 Jan;39(1):349-85. <DOI >.

11. Pandey MK, DeGrado TR. Glycogen Synthase Kinase-3 (GSK-3)-Targeted Therapy and Imaging. Theranostics. 2016;6(4):571-93. <DOI>.

12. Wei $P$, Liu B, Wang $R$, Gao $Y$, Li L, Ma $Y$, et al. Discovery of a series of dimethoxybenzene FGFR inhibitors with $5 \mathrm{H}$-pyrrolo[2,3-b]pyrazine scaffold: structure-activity relationship, crystal structural characterization and in vivo study. Acta Pharm Sin B. 2019 Mar;9(2):351-68. <DOI>.

13. Ahammad $F$, Tengku Abd Rashid TR, Mohamed M, Tanbin S, Ahmad Fuad FA. Contemporary Strategies and Current Trends in Designing Antiviral Drugs against Dengue Fever via Targeting Host-Based Approaches. Microorganisms. 2019 Aug 28;7(9):296. <DOI>.

14. Moine $\mathrm{E}$, Moiré $\mathrm{N}$, Dimier-Poisson I, Brunet $\mathrm{K}$, Couet W, Colas $\mathrm{C}$, et al. Imidazo[1,2b]pyridazines targeting Toxoplasma gondii calciumdependent protein kinase 1 decrease the parasite burden in mice with acute toxoplasmosis. Int J Parasitol. 2018 Jun;48(7):561-8. <DOI.

15. He Z-X, Gong Y-P, Zhang X, Ma L-Y, Zhao W. Pyridazine as a privileged structure: An updated review on anticancer activity of pyridazine containing bioactive molecules. Eur J Med Chem. 2021 Jan;209:112946. <DOI>.

16. Werbel LM, Worth DF. Chapter 13. Antiparasitic Agents. In: Annual Reports in Medicinal Chemistry [Internet]. Elsevier; 1980 [cited 2021 Jun 22]. p. 120-9. ISBN: 978-0-12-040515-2. $\leq U R L>$.

17. Sruthi K, Sumakanth $M$, Mahendra KC, Naresh K. Synthesis, in silico and in vitro antiproliferative studies of some novel benzamido substituted imidazo[1,2-b]pyridazin-2-ones. Ank Üniversitesi Eczacl Fakültesi Derg. 2017;41(1):925. $\leq \mathrm{DOI}>$.

18. Schirrmacher R, Bailey JJ, Mossine AV, Scott $\mathrm{PJH}$, Kaiser $\mathrm{L}$, Bartenstein $\mathrm{P}$, et al. Radioligands for Tropomyosin Receptor Kinase (Trk) Positron Emission Tomography Imaging. Pharmaceuticals. 2019 Jan $3 ; 12(1): 7$. <DOI $>$.

19. Margrey KA, McManus JB, Bonazzi S, Zecri F, Nicewicz DA. Predictive Model for Site-Selective Aryl and Heteroaryl $\mathrm{C}-\mathrm{H}$ Functionalization via Organic Photoredox Catalysis. J Am Chem Soc. 2017 Aug 16;139(32):11288-99. <DOI>. 
20. Chen S, Liu L, Gao X, Hua Y, Peng L, Zhang $Y$, et al. Addition of alkynes and osmium carbynes towards functionalized $\mathrm{dn}-\mathrm{p} п$ conjugated systems. Nat Commun. 2020 Dec;11(1):4651. <DOI>.

21. Liu S, Pan P, Fan H, Li H, Wang W, Zhang Y. Photocatalytic $\mathrm{C}-\mathrm{H}$ silylation of heteroarenes by using trialkylhydrosilanes. Chem Sci. 2019;10(13):3817-25. <DOI>.

22. Yan H, Hou Z, Xu H. Photoelectrochemical $\mathrm{C}-\mathrm{H}$ Alkylation of Heteroarenes with Organotrifluoroborates. Angew Chem Int Ed. 2019 Mar 26;58(14):4592-5. <DOI>.

23. Hu X, Zhang G, Bu F, Luo X, Yi K, Zhang $\mathrm{H}_{\text {, }}$ et al. Photoinduced oxidative activation of electronrich arenes: alkenylation with $\mathrm{H}_{2}$ evolution under external oxidant-free conditions. Chem Sci. 2018;9(6):1521-6. <DOI .

24. Štefane B, Polanc S. CAN-Mediated Oxidation of Electron-Deficient Aryl and Heteroaryl Hydrazines and Hydrazides. Synlett. 2008 May;2008(9):1279-82. <DOI>.

25. Stanovnik B, Tisler M, Drnovsek I. 3bromoimidazo (1,2-b)pyridazine-bromine and 3bromo-6-chloroimidazo (1,2-b) pyridazine-bromine complexes; new brominating agents for organic compounds. Synthesis. 1981;(12):987-9. <DOI>.

26. Song $W, X u Q$, Zhu J, Chen $Y, M u ~ H$, Huang $\mathrm{J}$, et al. Imidazo[1,2- $b$ ]pyridazine as Building Blocks for Host Materials for High-Performance RedPhosphorescent Organic Light-Emitting Devices. ACS Appl Mater Interfaces. 2020 Apr 29;12(17):197019. $\leq \mathrm{DOI}>$.

27. Lin S, Hao P, Shen J, Fu Y. Hierarchically responsive and photochromic imidazopyridazinium iodoargentate hybrid materials. Dyes Pigments. 2018 Dec;159:457-63. <DOI>.

28. Ma Y, Liang J, Zhao D, Chen Y-L, Shen J, Xiong $B$. Condensed Fukui function predicts innate $\mathrm{C}-\mathrm{H}$ radical functionalization sites on multi-nitrogen containing fused arenes. RSC Adv. 2014;4(33): 17262-4. <DOI>.

29. Roskoski R. Properties of FDA-approved small molecule protein kinase inhibitors. Pharmacol Res. 2019 Jun; 144:19-50. <DOI>.

30. Hu L, Cao T, Lv Y, Ding Y, Yang L, Zhang Q, et al. Design, synthesis, and biological activity of 4(imidazo[1,2- b ]pyridazin-3-yl)-1 H -pyrazol-1-ylphenylbenzamide derivatives as $B C R-A B L$ kinase inhibitors. Bioorg Med Chem Lett. 2016 Dec;26(23):5830-5. <DOI>.

31. Lambert GK, Duhme-Klair A-K, Morgan T, Ramjee MK. The background, discovery and clinical development of BCR-ABL inhibitors. Drug Discov Today. 2013 Oct;18(19-20):992-1000. <DOI>.

32. Lee HJ, Pham PC, Hyun SY, Baek B, Kim B, Kim $Y$, et al. Development of a 4aminopyrazolo[3,4-d]pyrimidine-based dual IGF1R/Src inhibitor as a novel anticancer agent with minimal toxicity. Mol Cancer. 2018 Dec;17(1):50. $\leq \mathrm{DOI}$.

33. Larocque E, Chu EFY, Naganna N, Sintim HO. Nicotinamide-Ponatinib Analogues as Potent Anti-CML and Anti-AML Compounds. ACS Omega. 2020 Feb 18;5(6):2690-8. <DOI>.

34. Miyamoto N, Sakai N, Hirayama T, Miwa $K$, Oguro $Y$, Oki $H$, et al. Discovery of $N-[5-(\{2-$ [(cyclopropylcarbonyl)amino]imidazo[1,2-

b Jpyridazin-6-yl\}oxy)-2-methylphenyl]-1,3dimethyl-1 H -pyrazole-5-carboxamide (TAK-593), a highly potent VEGFR2 kinase inhibitor. Bioorg Med Chem. 2013 Apr;21(8):2333-45. <DOI>.

35. Shen Y-M, Lv P-C, Chen W, Liu P-G, Zhang $\mathrm{M}-\mathrm{Z}$, Zhu H-L. Synthesis and antiproliferative activity of indolizine derivatives incorporating a cyclopropylcarbonyl group against Hep-G2 cancer cell line. Eur J Med Chem. 2010 Jul;45(7):3184-90. $\leq$ DOI $>$.

36. Chidella K, Seelam N, Cherukumalli PKR, Reddy N J, Sridhar G. Design and synthesis of novel 1,2,4-Thiadiazole linked imidazo[1,2-b]pyridazine as anticancer agents. Chem Data Collect. 2020 Dec;30:100554. <DOI $>$.

37. Tewari N, Mohammad K, Rai B, Prakash $\mathrm{H}$, Hussain M. Processes for the preparation of cefozopran, its salts and polymorphic forms thereof [Internet]. WO2010/89729. p. 57. $\leq U R L>$.

38. Jankowska A, Świerczek A, Wyska E, Gawalska A, Bucki A, Pawłowski M, et al. Advances in Discovery of PDE10A Inhibitors for CNS-Related Disorders. Part 1: Overview of the Chemical and Biological Research. Curr Drug Targets. 2018 Nov 27;20(1):122-43. <DOI>.

39. Juillet $\mathrm{C}$, Ermolenko L, Boyarskaya D, Baratte B, Josselin B, Nedev $H$, et al. From Synthetic Simplified Marine Metabolite Analogues to New Selective Allosteric Inhibitor of Aurora B Kinase. J Med Chem. 2021 Jan 28;64(2):1197-219. $\leq \mathrm{DOI}>$.

40. Shannan B, Watters A, Chen Q, Mollin S, Dörr M, Meggers E, et al. PIM kinases as therapeutic targets against advanced melanoma. Oncotarget. 2016 Aug 23;7(34):54897-912. <DOI>.

41. Foulks JM, Carpenter KJ, Luo B, Xu Y, Senina A, Nix R, et al. A Small-Molecule Inhibitor of PIM Kinases as a Potential Treatment for Urothelial 
Carcinomas. Neoplasia. 2014 May;16(5):403-12. $<\mathrm{DOI}>$.

42. Moslin $\mathrm{R}$, Zhang $\mathrm{Y}$, Wrobleski ST, Lin $\mathrm{S}$, Mertzman $M$, Spergel $S$, et al. Identification of $N$ Methyl Nicotinamide and N -Methyl Pyridazine-3Carboxamide Pseudokinase Domain Ligands as Highly Selective Allosteric Inhibitors of Tyrosine Kinase 2 (TYK2). J Med Chem. 2019 Oct 24;62(20):8953-72. <DOI>.

43. Moslin R, Gardner D, Santella J, Zhang $Y$, Duncia JV, Liu C, et al. Identification of imidazo[1,2$b$ ]pyridazine TYK2 pseudokinase ligands as potent and selective allosteric inhibitors of TYK2 signalling. MedChemComm. 2017;8(4):700-12. <DOI>.

44. Yeh V, Judd AS, Souers AJ. Chapter 11 Lipid-Metabolizing Enzymes as Targets for Dyslipidemia and Insulin Resistance. In: Annual Reports in Medicinal Chemistry [Internet]. Elsevier; 2007 [cited 2021 Jun 22]. p. 161-75. ISBN: 978-012-373912-4. $\leq$ URL $>$.

45. He $Y$, Wu JB, Lei $F$, Chen $P$, Hai L, Wu Y. Design, synthesis and antibacterial activity of novel 1-oxacephem analogs. Chin Chem Lett. 2012 Apr;23(4):407-10. <DOI>.

46. Özbek O, Gürdere MB. A review on the synthesis and applications of molecules as anticonvulsant drug agent candidates. Med Chem Res. 2020 Sep;29(9):1553-78. <DOI>.

47. Özbek O, Gürdere MB. Synthesis and anticancer properties of 2-aminothiazole derivatives. Phosphorus Sulfur Silicon Relat Elem. 2021 May $4 ; 196(5): 444-54$. $\leq$ DOI $>$.

48. Kobe J, Stanovnik B, Tišler T. Synthesis of pyridazine derivatives-XV. Tetrahedron. 1968 Jan;24(1):239-45. <DOI $>$.

49. Heinisch $G$, Lötsch $G$, Offenberger S, Stanovnik B, Tisler M. Preparation of azolopyridazinecarboxylic acids. J Heterocycl Chem. 1989;26(6):1751-4. <DOI>.

50. Ishikawa $T$, Iizawa $Y$, Okonogi $K$, Miyake A. Studies on Anti-MRSA Parenteral Cephalosporins. I. Synthesis and Antibacterial Activity of 7.BETA.-[2(5-Amino-1,2,4-thiadiazol-3-yl)-2(Z)hydroxyiminoacetamido]-3-(substituted imidazo [1,2-b]-pyridazinium-1-yl)methyl-3-cephem-4carboxylates and Related Compounds. J Antibiot (Tokyo). 2000;53(10):1053-70. <DOI>.

51. Matsumoto S, Miyamoto N, Hirayama T, Oki H, Okada K, Tawada M, et al. Structure-based design, synthesis, and evaluation of imidazo[1,2b]pyridazine and imidazo[1,2-a]pyridine derivatives as novel dual c-Met and VEGFR2 kinase inhibitors.
Bioorg Med Chem. 2013 Dec;21(24):7686-98. $\leq \mathrm{DOI}>$.

52. Hou Z, Xu H. Electrophotocatalytic $\mathrm{C}-\mathrm{H}$ Azolation of Arenes. ChemElectroChem. 2021 May 3;8(9):1571-3. <DOI .

53. $\mathrm{Xu} \mathrm{P}$, Chen $\mathrm{P}, \mathrm{Xu} H$. Scalable Photoelectrochemical Dehydrogenative CrossCoupling of Heteroarenes with Aliphatic $\mathrm{C}-\mathrm{H}$ Bonds. Angew Chem. 2020 Aug 17;132(34):14381-6. $\leq \mathrm{DOI}>$.

54. Huang $H$, Li H, Cordier $M$, Soulé J, Doucet $H$. Pd-Catalyzed Direct Arylations of Heteroarenes with Polyfluoroalkoxy-Substituted Bromobenzenes. Eur J Org Chem. 2020 Oct 15;2020(38):6094-101. <DOI $>$.

55. Mao S, Li $H$, Shi $X$, Soulé J, Doucet $H$. Environmentally Benign Arylations of 5-Membered Ring Heteroarenes by Pd-Catalyzed $\mathrm{C}-\mathrm{H}$ Bonds Activations. ChemCatChem. 2019 Jan 9;11(1):26986. $\leq \mathrm{DOI}>$.

56. Bouzayani B, Ben Salem R, Soulé J-F, Doucet $H$. Synthesis of C9,C10-Diheteroarylated Phenanthrenes via Palladium-Catalyzed C-H Bond Activation: Synthesis of C9,C10-Diheteroarylated Phenanthrenes via Palladium-Catalyzed $\mathrm{C}-\mathrm{H}$ Bond Activation. Eur J Org Chem. 2018 Dec 2;2018(44):6092-100. <DOI >.

57. Mao S, Shi X, Soulé J-F, Doucet H. Exploring Green Solvents Associated to $\mathrm{Pd} / \mathrm{C}$ as Heterogeneous Catalyst for Direct Arylation of Heteroaromatics with Aryl Bromides. Adv Synth Catal. 2018 Sep 3;360(17):3306-17. <DOI>.

58. Chikhi S, Djebbar S, Soulé J-F, Doucet $H$. Environmentally-Safe Conditions for a PalladiumCatalyzed Direct C3-Arylation with High Turn Over Frequency of Imidazo[1,2- $b$ ]pyridazines Using Aryl Bromides and Chlorides. Chem - Asian J. 2016 Sep 6;11(17):2443-52. <DOI .

59. Bellina $F$, Rossi R. Recent advances in the synthesis of (hetero)aryl-substituted heteroarenes via transition metal-catalysed direct (hetero)arylation of heteroarene $\mathrm{C}-\mathrm{H}$ bonds with aryl halides or pseudohalides, diaryliodonium salts, and potassium aryltrifluoroborates. Tetrahedron. 2009 Dec;65(50):10269-310. <DOI>.

60. Gu Y, Shen Y, Zarate C, Martin R. A Mild and Direct Site-Selective $s p 2 \mathrm{C}-\mathrm{H}$ Silylation of (Poly)Azines. J Am Chem Soc. 2019 Jan 9;141(1):127-32. <DOI>.

61. Handa $S$, Jin B, Bora PP, Wang $Y$, Zhang $X$, Gallou $F$, et al. Sonogashira Couplings Catalyzed by Fe Nanoparticles Containing ppm Levels of Reusable 
Pd, under Mild Aqueous Micellar Conditions. ACS Catal. 2019 Mar;9(3):2423-31. <DOI>.

62. Saikia I, Borah AJ, Phukan P. Use of Bromine and Bromo-Organic Compounds in Organic Synthesis. Chem Rev. 2016 Jun 22;116(12):68377042. $\leq$ DOI $>$.

63. Tagore SS, Swaminathan J, Manikandan D, Gomathi S, Nirmal Ram S, Ramalingam M, et al. Molecular, vibrational (FT-IR and FT-Raman), NMR and UV spectral analysis of imidazo[1,2b]pyridazine using experimental and DFT calculations. Chem Phys Lett. 2020 Jan;739:136943. <DOI $>$.

64. Miyashita $M$, Akamatsu $M$, Ueno $H$, Nakagawa $Y$, Nishimura K, Hayashi $Y$, et al. Structure-Activity Relationships of RGD Mimetics as Fibrinogen-Receptor Antagonists. Biosci Biotechnol Biochem. 1999 Jan;63(10):1684-90. <DOI>.

65. Pugmire RJ, Smith JC, Grant DM, Stanovnik $B$, Tišler $M$, Verček $B$. Correlation of ring nitrogen substituents with carbon-13 nuclear magnetic resonance data in azoloazines. J Heterocycl Chem. 1987 May;24(3):805-9. <DOI>.

66. Downing JW, Waluk JW, Stanovnik B, Michl J. Applications of magnetic circular dichroism: a Hammett-like equation for structural work. Determination of protonation sites in azaindolizines. J Org Chem. 1985;50(3):302-11. <URL >.

67. Stefaniak L, Roberts JD, Witanowski M, Hamdi BT, Webb GA. A15N NMR investigation of some azolopyridines. Org Magn Reson. 1984 Apr;22(4):209-14. <DOI $>$.

68. Kovać $B$, Klasinc L, Stanovnik B, Tišler $M$. Photoelectron spectroscopy of heterocycles. Azaindenes and azaindolizines. J Heterocycl Chem. 1980 Jun;17(4):689-94. <DOI>. 
Akkurt B. JOTCSA. 2021; 8(4): 1217-1250. 